Article

\title{
Strontium Phosphate Composite Designed to Red-Emission at Different Temperatures
}

\author{
Katarzyna Szyszka *(D), Adam Watras ${ }^{(D)}$ and Rafal J. Wiglusz *(D) \\ Institute of Low Temperature and Structure Research, Polish Academy of Sciences, Okolna 2, \\ 50-422 Wroclaw, Poland; a.watras@intibs.pl \\ * Correspondence: k.szyszka@intibs.pl (K.S.); r.wiglusz@intibs.pl (R.J.W.); \\ Tel.: +48-71-3954-274 (K.S.); +48-71-3954-159 (R.J.W.)
}

Received: 8 September 2020; Accepted: 6 October 2020; Published: 9 October 2020

\begin{abstract}
Eu}^{3+}$-doped $\mathrm{Sr}_{10}\left(\mathrm{PO}_{4}\right)_{6}(\mathrm{OH})_{2}-\mathrm{Sr}_{3}\left(\mathrm{PO}_{4}\right)_{2}$ (SrHAp-TSP) composites were obtained via the microwave-stimulated hydrothermal method and post-heat-treated from 750 to $950^{\circ} \mathrm{C}$. Concentration of the $\mathrm{Eu}^{3+}$ ions was set to be $0.5,1,2,3,5 \mathrm{~mol} \%$ in a ratio of the strontium ions molar content. The structural and morphological properties were investigated by $\mathrm{X}$-ray powder diffraction (XRPD), scanning electron microscopy (SEM) and fourier transform infrared spectroscopy (FT-IR) techniques. The average particle size of the studied materials annealed at 750,850 and $950{ }^{\circ} \mathrm{C}$ were counted about 100, 131 and $173 \mathrm{~nm}$, respectively. The luminescence properties depending on the dopant ion concentration, heat-treatment temperature, excitation wavelength and temperature were investigated. In the emission spectra, a broad peak corresponding to the $4 f^{6} 5 d^{1} \rightarrow 4 f^{7}\left({ }^{8} S_{7 / 2}\right)$ emission of $\mathbf{E u}^{2+}$ ions as well as narrow $4 \mathrm{f}-4 \mathrm{f}$ transitions typical for $\mathrm{Eu}^{3+}$ ions can be observed. The luminescence intensity of the $1 \mathrm{~mol} \% \mathrm{Eu}^{3+}: \mathrm{Sr}_{10}\left(\mathrm{PO}_{4}\right)_{6}(\mathrm{OH})_{2}-\mathrm{Sr}_{3}\left(\mathrm{PO}_{4}\right)_{2}$ was measured depending on the ambient temperature in the range of 80-550 K. The CIE 1931 (International Commission on Illumination) chromaticity diagram was determined from emission spectra measured in 80,300 and $550 \mathrm{~K}$. The reduction mechanism of the $\mathrm{Eu}^{3+}$ to the $\mathrm{Eu}^{2+}$ was explained by the charge compensation mechanism based on the Kröger-Vink-notation. The decay times were measured and the Judd-Ofelt (J-O) theory was applied to analyze the observed structural and spectroscopic features.
\end{abstract}

Keywords: luminescence; strontium hydroxyapatite; strontium phosphate; europium (III) ions; biomaterial; hydrothermal synthesis; Kröger-Vink-notation

\section{Introduction}

Apatite (Ap) is a large family of compounds commonly occurring in nature. Calcium hydroxyapatite $\left(\mathrm{Ca}_{10}\left(\mathrm{PO}_{4}\right) 6(\mathrm{OH})_{2}-\mathrm{CaHAp}\right)$ is ideal representative of this family of minerals, which can be easily doped with different kinds of ions [1,2]. Apatite is applied in plenty industrial fields as catalysts, laser hosts, luminescent materials, gas sensors, ionic conductors and adsorbents $[3,4]$. Moreover, calcium phosphates are also used in implantology due to high similarity to the inorganic part of hard tissues in bones, high biocompatibility, osteoconductivity, nontoxicity, non-immunogenicity and bioactivity [5-7] Apatite doped with lanthanide ions are extensively investigated as bio-labels that can be used in in vitro and in vivo imaging [8-10].

Strontium is a trace element present in human bones and tooth impacting on the strength, healing, microarchitecture, and bone formation. Besides, strontium (II) ions were employed in osteoporosis therapy in the form of orally administrated strontium ranelate salt [11]. Moreover, strontium apatites seem to be good candidates as host lattices for luminescent dopants due to their excellent thermal and chemical stability as well as excellent luminescence properties. As an example, the $\mathrm{Sr}_{5}\left(\mathrm{PO}_{4}\right)_{3} \mathrm{Cl}$ : $\mathrm{Eu}^{2+}$ material was used as the blue component in fluorescent lamp [12]. 
Designing of phosphor materials activated by lanthanide ions has enabled their applications in such technologies as solid-state lighting, flat panel displays, light-emitting diodes (LEDs), biological diagnostic, and biomedical areas due to their excellent properties [13]. $\mathrm{Eu}^{3+}$ ions are the most frequently used activator applied as red-emitting phosphor e.g., in commercially available phosphors $\mathrm{Y}_{2} \mathrm{O}_{2} \mathrm{~S}: \mathrm{Eu}^{3+}$ and $\mathrm{Y}_{2} \mathrm{O}_{3}: \mathrm{Eu}^{3+}[14,15]$. Moreover, europium can occur in $\mathrm{Eu}^{2+}\left(\mathrm{f}^{7}\right)$ and $\mathrm{Eu}^{3+}\left(\mathrm{f}^{6}\right)$ oxidation states of suitable stability. Both show many different features as emitting centers. The $\mathrm{Eu}^{2+}$ ion is sensitive to oxidation under some conditions; however, it possesses good stability in the solid-state materials. It is of particular interest because it exhibits strong and tunable emission from blue to red [16]. The emission spectrum consists of the broad band related to the allowed $4 f^{6} 5 d^{1} \rightarrow 4 f^{7}\left({ }^{8} S_{7 / 2}\right)$ transition. Its luminescence properties strongly depend on its environment in the host lattice. The $\mathrm{Eu}^{3+}$ ion is also characterized by unique optical properties with a relatively strong red-orange emission. Its luminescence results from forbidden, intra-configurational $\mathrm{f}-\mathrm{f}$ transitions roughly independent on crystal field influence. However, the intensity of particular transitions are highly sensitive to Eu ${ }^{3+}$ ions surrounding, so additionally, $\mathrm{Eu}^{3+}$ ions are very useful as a luminescence probe [17-19].

Luminescence materials co-doped with $\mathrm{Eu}^{3+}$ and $\mathrm{Eu}^{2+}$ is tough to obtain because the reduction of oxidation state in solid states requires a thermal treatment in reducing atmosphere $\left(\mathrm{H}_{2}, \mathrm{H}_{2} / \mathrm{N}_{2}, \mathrm{CO}\right)$. However, it is interesting that $\mathrm{Eu}^{2+}$-doped materials can be obtained in a nonreducing atmosphere at elevated temperatures in certain compounds due to reduction of $\mathrm{Eu}^{3+}$ ions to $\mathrm{Eu}^{2+}$ ions by the crystallographic site [20]. This abnormal reduction phenomenon was observed in crystal structures with $\mathrm{BO}_{4}, \mathrm{SiO}_{4}, \mathrm{AlO}_{4}$, or $\mathrm{PO}_{4}$ tetrahedral groups.

In the present work, for the first time to the best of our knowledge [7,8,21-24], synthesis of strontium phosphate composite $\left(\mathrm{Sr}_{10}\left(\mathrm{PO}_{4}\right)_{6}(\mathrm{OH})_{2}-\mathrm{Sr}_{3}\left(\mathrm{PO}_{4}\right)_{2}\right)$ co-doped with $\mathrm{Eu}^{3+}$ and $\mathrm{Eu}^{2+}$ ions prepared in the air at high temperature and the structural, morphological as well as spectroscopic properties have been studied.

\section{Materials and Methods}

\subsection{Synthesis of Composite}

Strontium phosphate $\left(\mathrm{Sr}_{10}\left(\mathrm{PO}_{4}\right)_{6}(\mathrm{OH})_{2}-\mathrm{Sr}_{3}\left(\mathrm{PO}_{4}\right)_{2}\right)$ composite doped with $\mathrm{Eu}^{3+}$ ions was synthesised by microwave stimulated hydrothermal method and then post-treated at elevated temperature [7,8]. The $\mathrm{Sr}\left(\mathrm{NO}_{3}\right)_{2}\left(99.0 \%\right.$ min Alfa Aesar, Karlsruhe, Germany), $\left(\mathrm{NH}_{4}\right)_{2} \mathrm{HPO}_{4}$ ( $\geq 99.0 \%$ Fluka, Bucharest, Romania), $\mathrm{Eu}_{2} \mathrm{O}_{3}$ (99.99\% Alfa Aesar, Karlsruhe, Germany) and $\mathrm{NH}_{3} \cdot \mathrm{H}_{2} \mathrm{O}$ (99\% Avantor, Gliwice, Poland) for $\mathrm{pH}$ modification were used as substrates. The $\mathrm{Eu}^{3+}$ ions concentration was set on $0.5,1,2,3$ and $5 \mathrm{~mol} \%$ in proportion of strontium ions molar content. Firstly, the stoichiometric $\mathrm{Eu}_{2} \mathrm{O}_{3}$ mass was digested in the $\mathrm{HNO}_{3}$ (ultrapure Avantor, Gliwice, Poland) to receive $\mathrm{Eu}\left(\mathrm{NO}_{3}\right)_{3} \cdot x \mathrm{H}_{2} \mathrm{O}$. Europium nitrate hydrate was re-crystallized three times in order to eliminate the $\mathrm{HNO}_{3}$ excess. Then, the stoichiometric $\mathrm{Sr}\left(\mathrm{NO}_{3}\right)_{2}$ mass was dissolved in water and the $\mathrm{Eu}\left(\mathrm{NO}_{3}\right)_{3} \cdot \mathrm{xH}_{2} \mathrm{O}$ also was added in. Thereafter, $0.5353 \mathrm{~g}(4.05 \mathrm{mmol})$ of $\left(\mathrm{NH}_{4}\right)_{2} \mathrm{HPO}_{4}$ was put to the previous mixture and the $\mathrm{pH}$ value was modified to 10 by means of ammonia. The suspension was transferred into Teflon vessel (Ertec, Wroclaw, Poland) and placed in the microwave hydrothermal reactor (MV 02-02, Ertec, Wroclaw, Poland). The mixture was heat treated at $280^{\circ} \mathrm{C}$ for $90 \mathrm{~min}$ under $60 \mathrm{~atm}$ autogenous pressure. The obtained product was rinsed with de-ionized water (Hydrolab, Straszyn, Poland) several times and dried at $70^{\circ} \mathrm{C}$ for $24 \mathrm{~h}$. The thermal treatment from 750 to $950{ }^{\circ} \mathrm{C}$ for $3 \mathrm{~h}$ was the last step during materials preparation.

\subsection{Characterisation}

Powder diffraction patterns were received by using an X'Pert Pro diffractometer (PANalytical, Almelo, The Netherlands) equipped with Ni-filtered $\mathrm{Cu} \mathrm{K} \alpha$ radiation $(\lambda=0.154 \mathrm{~nm}, \mathrm{~V}=40 \mathrm{kV}$, $\mathrm{I}=30 \mathrm{~mA}$ ). The structural refinement was done by using a Maud program version 2.93 (University of Trento - Italy, Department of Industrial Engineering, Trento, Italy) $[25,26]$ based on the apatite 
hexagonal and trigonal tristrontium diphosphate crystal structures with better approximation and indexing of the Crystallographic Information File (CIF). The quality of structural refinement was supervised by $R$-values $\left(R_{w}, R_{w n b}, R_{a l l}, R_{n b}\right.$, and $\left.\sigma\right)$, which were followed to get a structural refinement with better quality and reliability.

A FEI Nova NanoSEM 230 scanning electron microscope (Hillsboro, OR, USA) equipped with energy dispersive spectrometer spectrometer (EDS; EDAX Genesis XM4; Hillsboro, OR, USA) and operating at an acceleration voltage in the range 3.0-15.0 kV and spot 4.0-4.5 was used to determine the surface morphology and the elements mapping. The EDS analysis was done to confirm the contents of elements in the obtained materials.

A Nicolet iS50 FT-IR (Thermo Scientific, Waltham, MA, USA) spectrometer equipped with an Automated Beamsplitter exchange system (iS50 ABX containing DLaTGS KBr detector) (Thermo Scientific, Waltham, MA, USA) and HeNe laser as an IR radiation source were used to measure IR spectra. Polycrystalline mid-IR spectra were collected in the $4000-400 \mathrm{~cm}^{-1}$ range in $\mathrm{KBr}$ pellets at the temperature of $295 \mathrm{~K}$ and spectral resolution of $4 \mathrm{~cm}^{-1}$.

The excitation spectra were recorded using an FLS980 Fluorescence Spectrometer (Edinburgh Instruments, Kirkton Campus, UK) equipped with $450 \mathrm{~W}$ Xenon lamp. The excitation of $300 \mathrm{~mm}$ focal length monochromator was in Czerny-Turner configuration. The excitation arm was supplied with holographic grating of 1800 lines/mm grating blazed at $250 \mathrm{~nm}$. The excitation spectra were corrected to the excitation source intensity. The emission spectra were measured with a PMA-12 photonic multichannel analyser (Hamamatsu, Hamamatsu City, Japan) equipped with back-thinned charge-coupled device (BT-CCD) line (Hamamatsu, Hamamatsu City, Japan). As an excitation source a pulsed $266 \mathrm{~nm}$ line of Nd: YAG laser (3rd harmonic) and a pulsed $395 \mathrm{~nm}$ line from Ti: Sapphire tunable laser pumped by $532 \mathrm{~nm}$ line from Nd:YAG laser were used (LOTIS TII, Minsk, Belarus). The detection setup is calibrated and has flat response in whole working range (350-1100 nm). The measurements were carried out in $300 \mathrm{~K}$ and $80 \mathrm{~K}$ as well as in the temperature range 80-550 K using Linkam THMS600 cooling/heating stage (Linkam, Epsom, UK).

The luminescence kinetics were measured by using Jobin-Yvon THR1000 monochromator (HORIBA Jobin-Yvon, Palaiseu, France) equipped with Hamamatsu R928 photomultiplier (Hamamatsu, Hamamatsu City, Japan) and 1200 lines/mm grating blazed at $500 \mathrm{~nm}$. As an excitation source a pulsed $395 \mathrm{~nm}$ line from Ti: Sapphire tunable laser (LOTIS TII, Minsk, Belarus) pumped by $532 \mathrm{~nm}$ line from Nd: YAG laser was used. The decay profiles were collected using a LeCroy WaveSurfer $400 \mathrm{MHz}$ oscilloscope (Teledyne LeCroy, Chestnut Ridge, NY, USA). The luminescence kinetics were monitored at $612 \mathrm{~nm}$ line which is the maximum of the most intense electric dipole transition $\left({ }^{5} \mathrm{D}_{0} \rightarrow{ }^{7} \mathrm{~F}_{2}\right)$ and the effective emission lifetimes were calculated by the following equation:

$$
\tau_{\mathrm{m}} \frac{\int_{0}^{\infty} \mathrm{tI}(\mathrm{t}) \mathrm{dt}}{\int_{0}^{\infty} \mathrm{I}(\mathrm{t}) \mathrm{dt}} \cong \frac{\int_{0}^{\mathrm{t}^{\max }} \mathrm{tI}(\mathrm{t}) \mathrm{dt}}{\int_{0}^{\mathrm{t}^{\max }} \mathrm{I}(\mathrm{t}) \mathrm{dt}}
$$

where $\mathrm{I}(\mathrm{t})$ is the luminescence intensity at time $\mathrm{t}$ corrected for the background, and the integrals are calculated over the range of $0<t<t_{\max }$, where $t_{\max }>>\tau_{m}$.

A blue luminescence decay curve was excited by a femtosecond laser system Libra Series (Coherent, Wilsonville, USA; $1 \mathrm{~mJ}, 89 \mathrm{fs}, 800 \mathrm{~nm}$ ) coupled to a Light Conversion OPerA-Solo Optical Parametric Amplifier (Coherent, Wilsonville, USA) and a C5680 streak camera (Hamamatsu, Hamamatsu City, Japan) was used as a detector. The decay curve fitting was performed via Origin 2019 software (OriginLab, Northampton, MA, USA) by using following single exponential decay formula:

$$
\mathrm{I}(\mathrm{t})=\mathrm{I}_{0}+\mathrm{A} \exp (-\mathrm{t} / \tau)
$$

where $I(t)$ and $I_{0}$ are the luminescence intensity at time $t$ and $t>>\tau, A$ is a constant, and $\tau$ is the decay time for an exponential component. 


\section{Results and Discussion}

\subsection{Structural and Morphological Analysis}

The formation of the strontium phosphate composite $\left(\mathrm{Sr}_{10}\left(\mathrm{PO}_{4}\right)_{6}(\mathrm{OH})_{2}-\mathrm{Sr}_{3}\left(\mathrm{PO}_{4}\right)_{2}\right)$ doped with $\mathrm{x} \mathrm{mol} \% \mathrm{Eu}^{3+}$ ions crystalline powders (where $\mathrm{x}-0.5,1,2,3,5 \mathrm{~mol} \%$ ) was followed by the powder XRD measurements both as a function of annealing temperature and of concentration of dopant ions (see Figure 1). The crystallinity was detected for all prepared materials sintered at different temperatures $\left(750-950{ }^{\circ} \mathrm{C}\right.$ per $3 \mathrm{~h}$ ). The presence of both phases in the final product was confirmed by the correlation of the diffraction patterns with the reference standard of the hexagonal strontium hydroxyapatite ascribed to the $\mathrm{P}_{3} / \mathrm{m}$ space group form Inorganic Crystal Structure Database (ICSD-2866) [27] and the trigonal tristrontium diphosphate ascribed to the R3-m space group (ICSD-150869) [28]. All the materials heat-treated at $750-950{ }^{\circ} \mathrm{C}$ have shown detectable crystallinity in the form of sharp, narrow diffraction peaks. All registered diffraction peaks were assigned to the hydroxyapatite and tristrontium diphosphate. No extra diffraction peaks were observed. The ratio of strontium phases is different and are depended on the heat-treating temperature as well as on europium(III) ions concentration (see Table 1). With an increase of annealing temperature, the content of the $\mathrm{Sr}_{3}\left(\mathrm{PO}_{4}\right)_{2}$ crystal phase in composite increases due to the dehydration process of hydroxyapatite occurring at elevated temperature. It is not possible to detect any trend according to content of particular crystal phases when the concentration of the $\mathrm{Eu}^{3+}$ in composites increases. The $\mathrm{Sr}_{3}\left(\mathrm{PO}_{4}\right)_{2}$ crystal phase amount in composite increases form $37 \%$ for $750{ }^{\circ} \mathrm{C}$ temperature to $52 \%$ for $950{ }^{\circ} \mathrm{C}$ in thermally treated materials. This phenomenon is related to dehydration process occurring in hydroxyapatite matrix under elevated temperature.

Table 1. Unit cell parameters (a and c), crystal cell volume (V), the percentage of particular phases calculated based on the Rietveld methods, and refined factors $\left(\mathrm{R}_{\mathrm{W}}\right)$ presented for the $\mathrm{Sr}_{10}\left(\mathrm{PO}_{4}\right)_{6}(\mathrm{OH})_{2}-\mathrm{Sr}_{3}\left(\mathrm{PO}_{4}\right)_{2}$ powder composites as a function of dopant concentration and sintering temperature.

\begin{tabular}{|c|c|c|c|c|c|c|c|c|c|}
\hline \multirow{3}{*}{ Sample } & \multicolumn{6}{|c|}{ Cell Parameters } & \multicolumn{3}{|c|}{ Phase } \\
\hline & \multicolumn{3}{|c|}{$\begin{array}{c}\text { Belovite } \\
\mathrm{Sr}_{5}\left(\mathrm{PO}_{4}\right)_{3} \mathrm{OH}\end{array}$} & \multicolumn{3}{|c|}{$\begin{array}{l}\text { Tristrontium Bis(Phosphate(V)) } \\
\qquad \mathrm{Sr}_{3}\left(\mathrm{PO}_{4}\right)_{2}\end{array}$} & \multirow{2}{*}{\multicolumn{2}{|c|}{$\begin{array}{l}\text { SrHAp TSP } \\
(\%) \quad(\%)\end{array}$}} & \multirow[t]{2}{*}{$\mathbf{R}_{\mathrm{w}}$} \\
\hline & a $(\AA)$ & c ( $(\AA)$ & $\mathrm{V}\left(\AA^{3}\right)$ & a $(\AA)$ & c $(\AA)$ & $V\left(\AA^{3}\right)$ & & & \\
\hline s. c. & $9.745(1)$ & $7.265(1)$ & $597.49(15)$ & $5.3975(2)$ & $19.818(3)$ & $500.01(8)$ & - & - & - \\
\hline $\begin{array}{l}0.5 \% \mathrm{~mol} \mathrm{Eu}^{3+} \\
750{ }^{\circ} \mathrm{C}\end{array}$ & $9.769(1)$ & $7.282(1)$ & $601.84(07)$ & $5.3912(5)$ & $19.794(9)$ & $498.23(6)$ & 78.16 & 21.84 & 1.38 \\
\hline $\begin{array}{l}1 \% \mathrm{~mol} \mathrm{Eu}^{3+} \\
7500^{\circ} \mathrm{C}\end{array}$ & $9.767(3)$ & $7.282(1)$ & $601.59(43)$ & $5.3913(1)$ & $19.798(1)$ & $498.35(5)$ & 82.79 & 17.21 & 1.30 \\
\hline $\begin{array}{l}2 \% \mathrm{~mol} \mathrm{Eu}^{3+} \\
750{ }^{\circ} \mathrm{C}\end{array}$ & $9.769(2)$ & $7.278(5)$ & $601.51(01)$ & $5.3921(2)$ & $19.802(6)$ & $498.60(4)$ & 80.36 & 19.64 & 1.20 \\
\hline $\begin{array}{c}3 \% \mathrm{~mol} \mathrm{Eu}^{3+} \\
750{ }^{\circ} \mathrm{C}\end{array}$ & $9.758(9)$ & $7.270(1)$ & $599.49(65)$ & $5.3892(6)$ & $19.795(8)$ & $497.89(1)$ & 62.65 & 37.35 & 1.28 \\
\hline $\begin{array}{c}5 \% \mathrm{~mol} \mathrm{Eu}^{3+} \\
750{ }^{\circ} \mathrm{C} \\
\end{array}$ & $9.760(5)$ & $7.270(1)$ & $599.74(22)$ & $5.3886(5)$ & $19.796(7)$ & $497.80(6)$ & 80.55 & 19.45 & 1.55 \\
\hline $\begin{array}{l}3 \% \mathrm{~mol} \mathrm{Eu}^{3+} \\
850{ }^{\circ} \mathrm{C}\end{array}$ & $9.748(5)$ & $7.262(7)$ & $597.61(01)$ & $5.3904(1)$ & $19.798(7)$ & $498.18(9)$ & 50.81 & 49.19 & 2.12 \\
\hline $\begin{array}{l}3 \% \mathrm{~mol} \mathrm{Eu}^{3+} \\
950{ }^{\circ} \mathrm{C}\end{array}$ & $9.735(1)$ & 7.251 (1) & $595.11(44)$ & $5.3904(5)$ & $19.796(4)$ & $498.13(8)$ & 47.69 & 52.31 & 1.46 \\
\hline
\end{tabular}



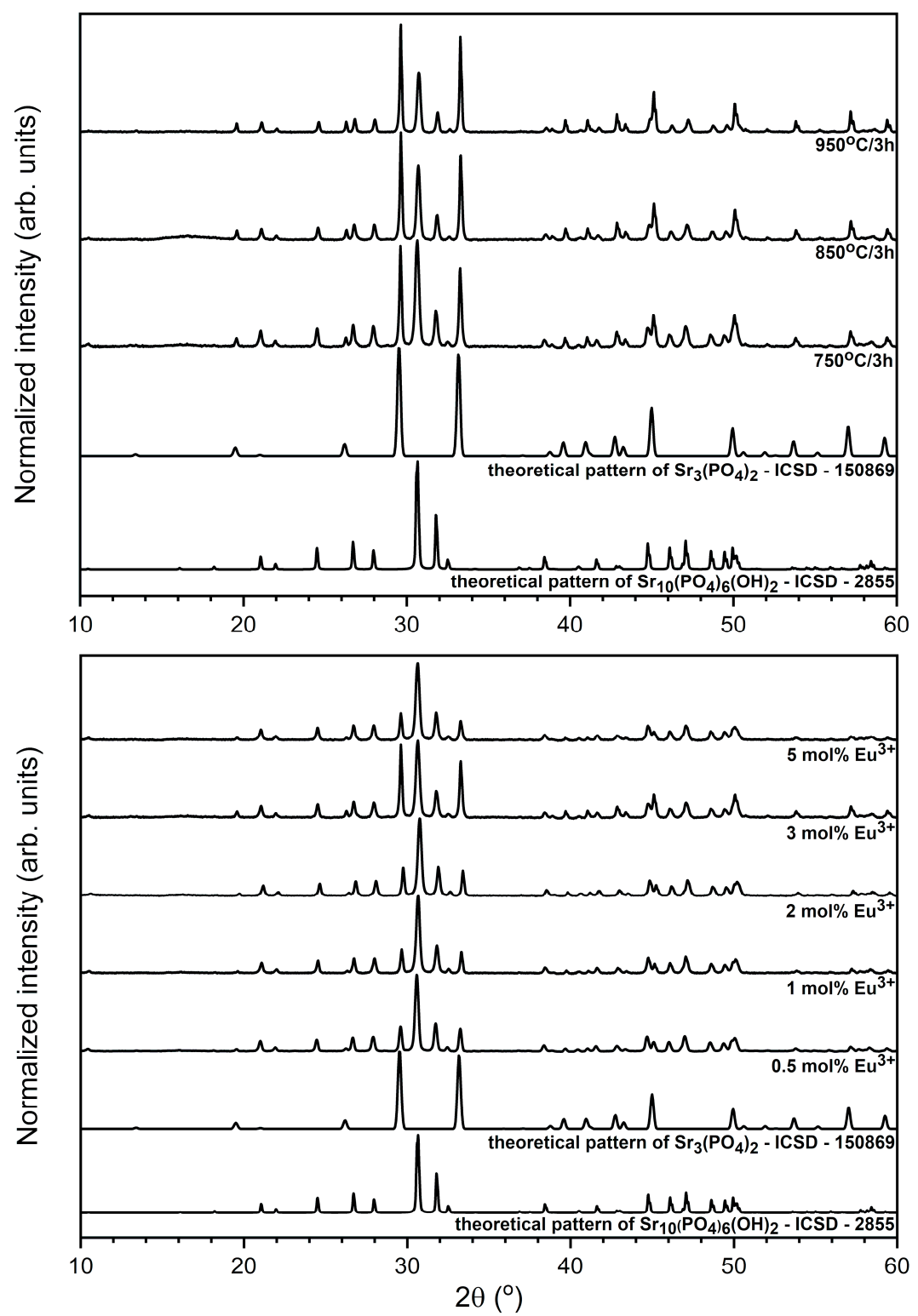

Figure 1. X-ray powder diffraction patterns of the $\mathrm{Sr}_{10}\left(\mathrm{PO}_{4}\right)_{6}(\mathrm{OH})_{2}-\mathrm{Sr}_{3}\left(\mathrm{PO}_{4}\right)_{2}$ composite doped with $3 \mathrm{~mol} \% \mathrm{Eu}^{3+}$ ions as a function of annealing temperature (up) and annealed at $750{ }^{\circ} \mathrm{C}$ composites as a function of dopant ions concentration (bottom).

The structural refinement has been performed to get the unit cell parameters and percentage composition of the composite. The hexagonal and trigonal phases formation as well as the effective incorporation of $\mathrm{Eu}^{3+}$ ions have been confirmed. A good agreement between the recorded XRD pattern and the theoretical fit has been found. It indicates the success of the Rietveld refinement method. More details regarding Rietveld refinement are displayed in Table 1. As can be seen, it is possible to observe a shrinkage of both cells volume and a parameters of the SrHAp as well as the TSP materials with an increase of the $\mathrm{Eu}^{3+}$ ions concentration, which is caused by smaller ionic radii of dopant $\left(\mathrm{Sr}^{2+}(\mathrm{CN} 9)-1.31 \AA, \mathrm{Eu}^{3+}(\mathrm{CN} 9)-1.12 \AA\right.$ and $\left.\mathrm{Sr}^{2+}(\mathrm{CN} 7)-1.21 \AA, \mathrm{Eu}^{3+}(\mathrm{CN} 7)-1.01 \AA\right)$ as well as tristrontium diphosphate $\left(\mathrm{Sr}^{2+}(\mathrm{CN} 6)-1.18 \AA, \mathrm{Eu}^{3+}(\mathrm{CN} 6)-0.947 \AA\right.$ and $\mathrm{Sr}^{2+}(\mathrm{CN} 10)-1.36 \AA$, $\left.\mathrm{Eu}^{3+}(\mathrm{CN} 9)-1.12 \AA\right)$ [29]. Moreover, the a and $\mathrm{V}$ cells parameters of both composite materials marginally decreased after thermal treatment, which is an expected and well-known consequence caused by increase of particle size. An increase of annealing temperature caused an increase of $\mathrm{Sr}_{3}\left(\mathrm{PO}_{4}\right)_{2}$ crystal phase content in composite. 
The visualization of the ideal hexagonal strontium apatite unit cell and trigonal tristrontium diphosphate unit cells as well as the coordination polyhedrals of $\mathrm{Sr}^{2+}$ cations is presented in Figure 2. Two different types of crystallographic sites of $\mathrm{Sr}^{2+}$ ions in hydroxyapatite lattice are current: four at the $\operatorname{Sr}(1)$ site with $C_{3}$ point symmetry situated on the ternary axes and six at the $\operatorname{Sr}(2)$ site with $C_{S}$ symmetry $[30,31]$. Moreover, in apatite structure, cis and trans symmetry of $C_{S}$ crystallographic site correlated with arrangements of $\mathrm{Eu}^{3+}$ ions along the channel is well-known [8]. In the $\mathrm{Sr}_{3}\left(\mathrm{PO}_{4}\right)_{2} \mathrm{matrix}_{\text {, }}$ there are two nonequivalent crystallographic sites of $\mathrm{Sr}^{2+}$ ions: three at the $\mathrm{Sr}(1)$ site and six at the $\operatorname{Sr}(2)$ site. The atoms at the $\operatorname{Sr}(1)$ crystallographic site are placed on the threefold axis coordinated by 6 oxygen atoms belonging to the $\mathrm{PO}_{4}{ }^{3-}$ group and site symmetry $\mathrm{C}_{3 \mathrm{v}}$. The ions at the $\mathrm{Sr}(2)$ site are coordinated by ten oxygen atoms having $\mathrm{C}_{\mathrm{S}}$ symmetry [32]. Nevertheless, a charge and an ionic radii incompatibility between $\mathrm{Sr}^{2+}$ and $\mathrm{Eu}^{3+}$ ions are present, leading to some structural defects correlated with the charge balance necessity.

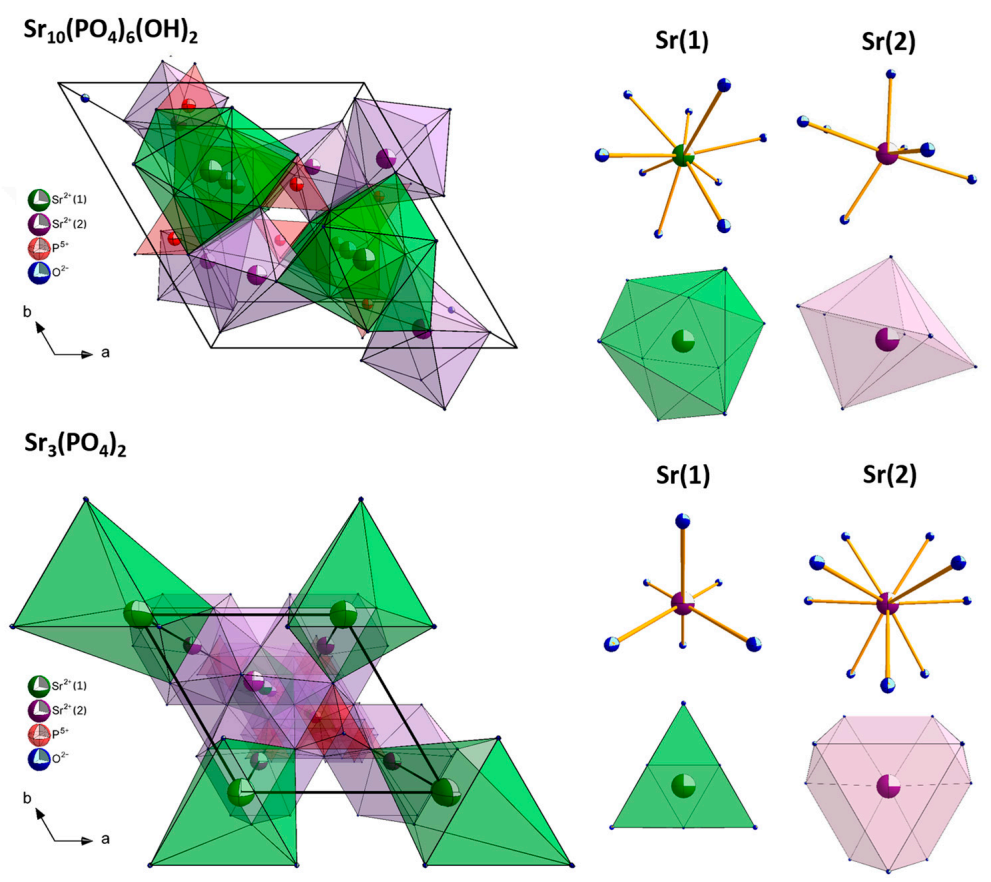

Figure 2. Visualization of the hexagonal strontium apatite and trigonal tristrontium diphosphate unit cells with the coordination polyhedra of the cations.

The morphology of the $\mathrm{Sr}_{10}\left(\mathrm{PO}_{4}\right)_{6}(\mathrm{OH})_{2}-\mathrm{Sr}_{3}\left(\mathrm{PO}_{4}\right)_{2}$ composite doped with $3 \mathrm{~mol} \% \mathrm{Eu}^{3+}$ ions annealed at 750, 850 and $950^{\circ} \mathrm{C}$ was studied using a Scanning Electron Microscope. The particles are aggregated, their shape is asymmetrical and elongated in one direction (see Figure 3 ). The morphology of particles was not changed with an increase of the annealing temperature. However, the particle size was changed with an increase of the annealing temperature. The particles size distributions were counted and displayed as histograms. The size distributions are relatively wide, which is caused by different grain growth speed of each phase. The average size of the $\mathrm{Sr}_{10}\left(\mathrm{PO}_{4}\right)_{6}(\mathrm{OH})_{2}-\mathrm{Sr}_{3}\left(\mathrm{PO}_{4}\right)_{2}$ composite doped with $3 \mathrm{~mol} \% \mathrm{Eu}^{3+}$ annealed at 750,850 and $950{ }^{\circ} \mathrm{C}$ are about $100( \pm 3.4), 131( \pm 2.6)$ and $173 \mathrm{~nm}( \pm 4.6 \mathrm{~nm})$, respectively. The energy-dispersive X-ray spectroscopy was used to confirm the content of elements in obtained materials.

The element maps were recorded by the SEM-EDS technique to analyze the elements distribution in the obtained material (Figure 4). The results confirmed the stated stoichiometry of dopants and regular distribution of elements. 
a)

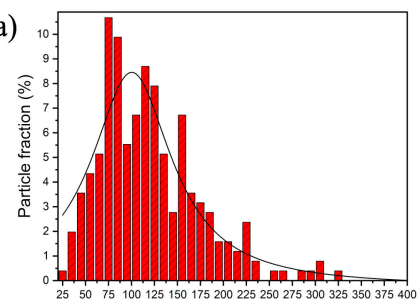

b)

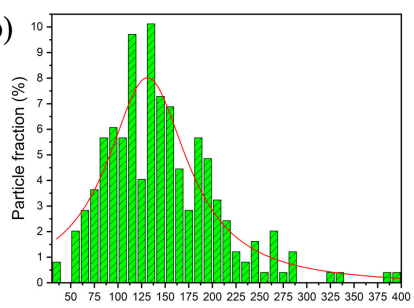

c)

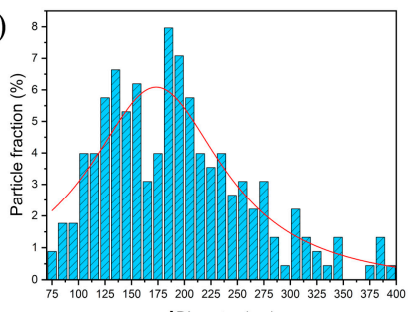

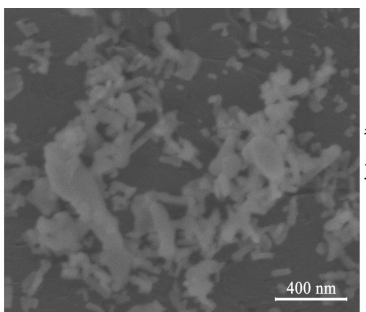
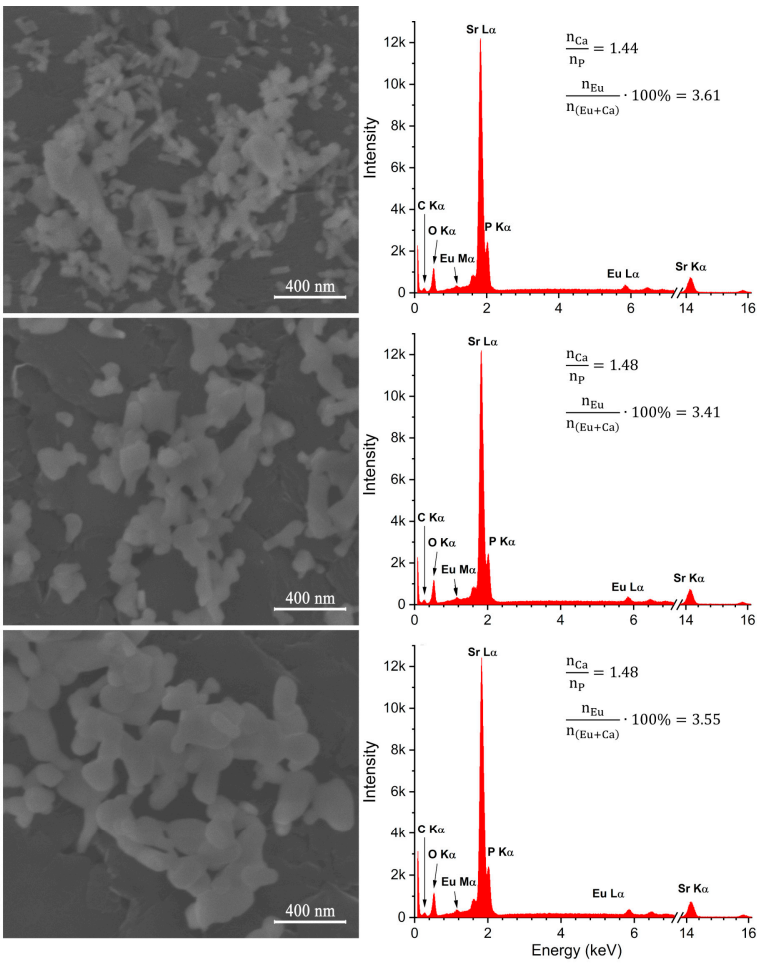

Figure 3. The particle size distribution (left) based on SEM images (middle) as well as EDS spectra (right) of the $\mathrm{Sr}_{10}\left(\mathrm{PO}_{4}\right)_{6}(\mathrm{OH})_{2}-\mathrm{Sr}_{3}\left(\mathrm{PO}_{4}\right)_{2}$ composite doped with $3 \mathrm{~mol} \% \mathrm{Eu}^{3+}$ ions annealed at $750{ }^{\circ} \mathrm{C}(\mathbf{a})$, $850{ }^{\circ} \mathrm{C}(\mathbf{b})$ and $950{ }^{\circ} \mathrm{C}(\mathbf{c})$.

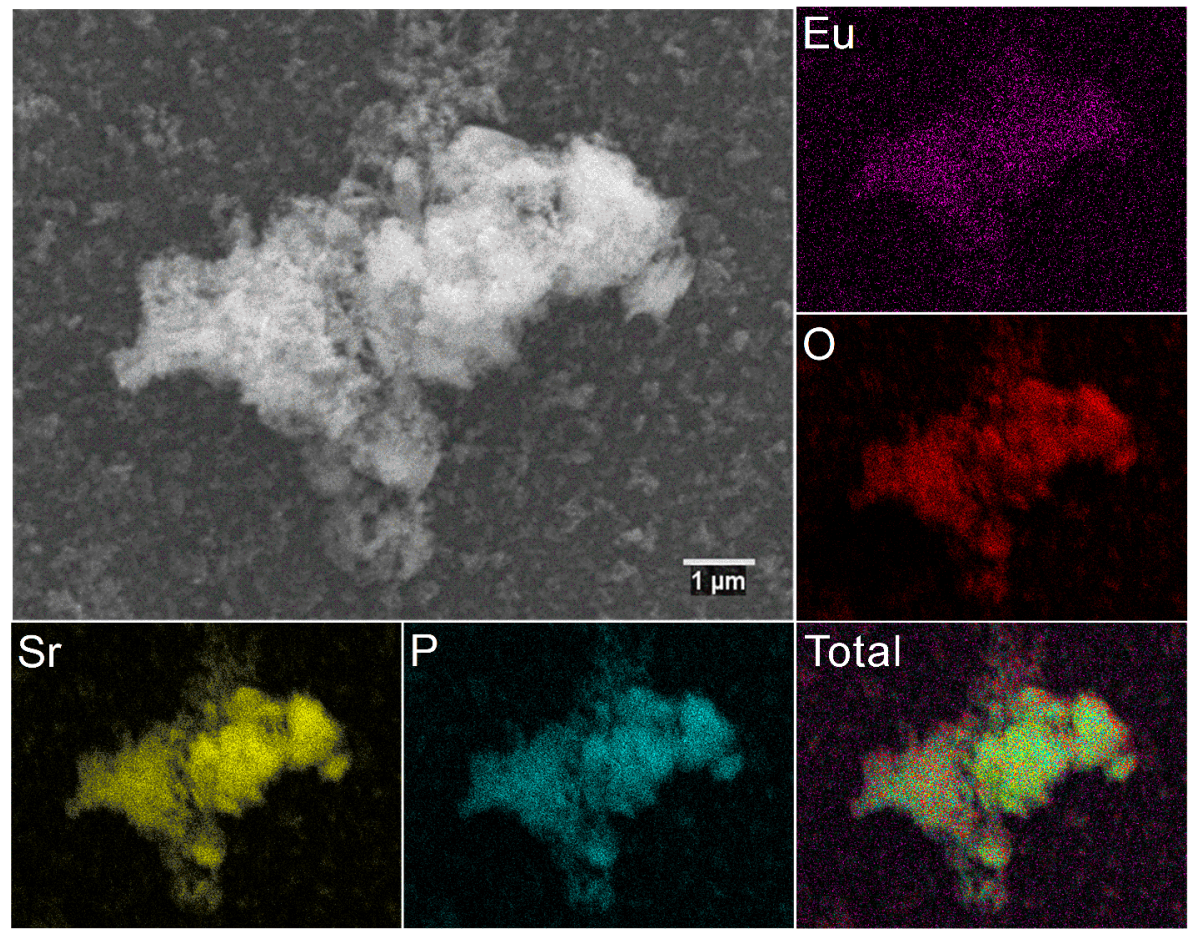

Figure 4. SEM image and EDS elemental maps of the $3 \mathrm{~mol} \% \mathrm{Eu}^{3+}: \mathrm{Sr}_{10}\left(\mathrm{PO}_{4}\right)_{6}(\mathrm{OH})_{2}-\mathrm{Sr}_{3}\left(\mathrm{PO}_{4}\right)_{2}$ composite annealed at $750{ }^{\circ} \mathrm{C}$. 
The FT-IR spectra were measured to identify the existence of orthophosphate and hydroxyl groups in obtained materials (Figure 5). The infrared spectra consist of ordinary $\mathrm{PO}_{4}{ }^{3-}$ vibration bands: the $\mathrm{v}_{2}$ bending at $448 \mathrm{~cm}^{-1} ; 564 \mathrm{~cm}^{-1}$, the $\mathrm{v}_{4}$ vibration at $596 \mathrm{~cm}^{-1}$; the $\mathrm{v}_{1}$ symmetric stretching at $950 \mathrm{~cm}^{-1}$; the $v_{3}$ antisymmetric stretching at $1033 \mathrm{~cm}^{-1}$ and $1081 \mathrm{~cm}^{-1}$. Moreover, the vibrational transitions observed at $1632 \mathrm{~cm}^{-1} 3432 \mathrm{~cm}^{-1}(\mathrm{v} \mathrm{OH})$ confirm the presence of a hydroxyl group in the obtained materials [33-35].

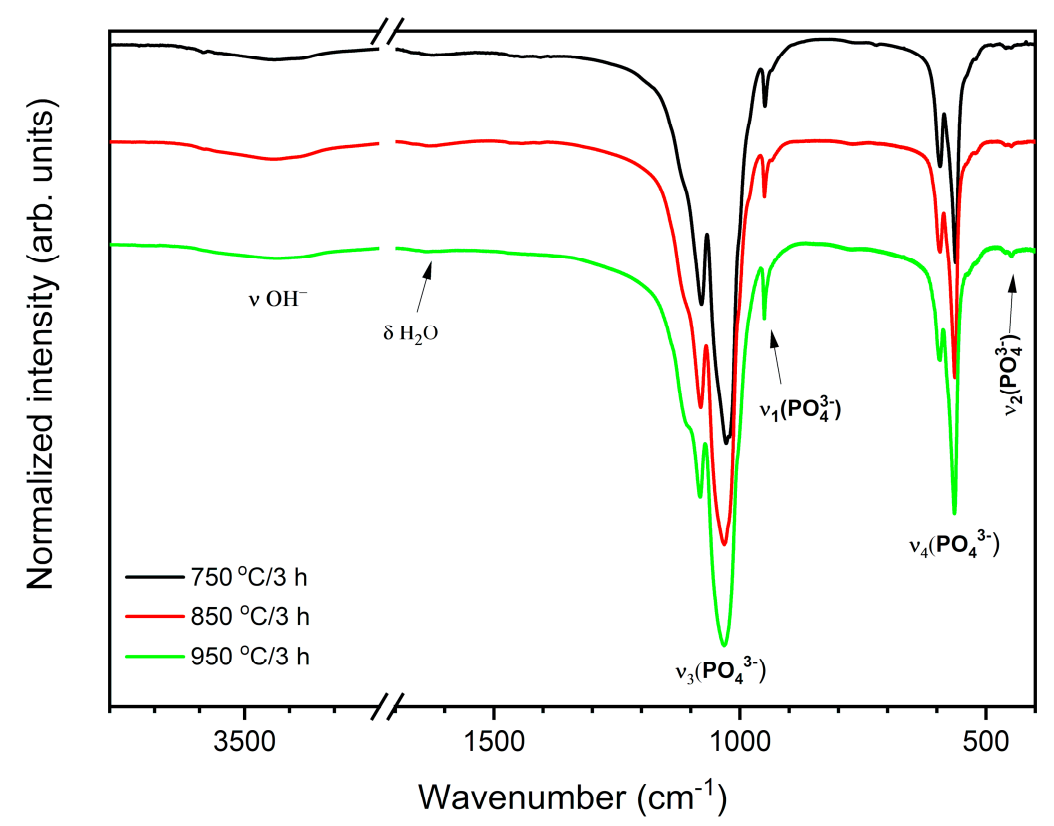

Figure 5. FT-IR spectra of the annealed $3 \mathrm{~mol} \% \mathrm{Eu}^{3+}: \mathrm{Sr}_{10}\left(\mathrm{PO}_{4}\right)_{6}(\mathrm{OH})_{2}-\mathrm{Sr}_{3}\left(\mathrm{PO}_{4}\right)_{2}$ composite annealed at different temperatures.

\subsection{Emission and Excitation Spectra}

The synthesised materials' excitation-emission spectra were measured at room temperature and observed at $615 \mathrm{~nm}$ emission wavelength of the maximum of the most intense ${ }^{5} \mathrm{D}_{0} \rightarrow{ }^{7} \mathrm{~F}_{2}$ electric dipole transition. All recorded spectra were alike to each other, thus only the representative excitation spectra of $1 \mathrm{~mol} \% \mathrm{Eu}^{3+}: \mathrm{Sr}_{10}\left(\mathrm{PO}_{4}\right)_{6}(\mathrm{OH})_{2}-\mathrm{Sr}_{3}\left(\mathrm{PO}_{4}\right)_{2}$ annealed at $750{ }^{\circ} \mathrm{C}$ was presented in Figure 6 . The weak intraconfigurational $4 \mathrm{f}-4 \mathrm{f}$ transitions with sharp lines are characteristic for the $\mathrm{Eu}^{3+}$ ions as well as the intense ligand-to-metal charge transfer $(\mathrm{CT}) \mathrm{O}^{2-} \rightarrow \mathrm{Eu}^{3+}$ with broad band in the UV range are typical for the $\mathrm{Eu}^{3+}$ ions incorporated into oxide matrix. The narrow lines observed at $339.5 \mathrm{~nm}\left(29,445 \mathrm{~cm}^{-1}\right)$ were attributed to the ${ }^{7} \mathrm{~F}_{0} \rightarrow{ }^{5} \mathrm{H}_{(6,5,4,7,3)}$ transitions, at $363 \mathrm{~nm}\left(27,548 \mathrm{~cm}^{-1}\right)$ to the ${ }^{7} \mathrm{~F}_{0} \rightarrow{ }^{5} \mathrm{D}_{4},{ }^{5} \mathrm{~L}_{8}$, the maximum at $383.5 \mathrm{~nm}\left(26,076 \mathrm{~cm}^{-1}\right)$ to the ${ }^{5} \mathrm{~L}_{8},{ }^{7} \mathrm{~F}_{0} \rightarrow \mathrm{G}_{2},{ }^{5} \mathrm{~L}_{7},{ }^{5} \mathrm{G}_{3}$, at $394.3 \mathrm{~nm}\left(25,361 \mathrm{~cm}^{-1}\right)$ to the ${ }^{7} \mathrm{~F}_{0} \rightarrow{ }^{5} \mathrm{~L}_{6}$, at $415.8 \mathrm{~nm}\left(24,050 \mathrm{~cm}^{-1}\right)$ to the ${ }^{7} \mathrm{~F}_{0} \rightarrow{ }^{5} \mathrm{D}_{3}$, at $465.3 \mathrm{~nm}\left(21,492 \mathrm{~cm}^{-1}\right)$ to the ${ }^{7} \mathrm{~F}_{0} \rightarrow{ }^{5} \mathrm{D}_{2}$, at $533.3 \mathrm{~nm}\left(18,751 \mathrm{~cm}^{-1}\right)$ to the ${ }^{7} \mathrm{~F}_{0} \rightarrow{ }^{5} \mathrm{D}_{1}$ and at $572 \mathrm{~nm}\left(17,483 \mathrm{~cm}^{-1}\right)$ to the ${ }^{7} \mathrm{~F}_{0} \rightarrow{ }^{5} \mathrm{D}_{0}$ transition. It is well known that the $4 \mathrm{f}$-sub-shells of lanthanide ions $\left(\mathrm{RE}^{3+}\right)$ are well protected by the $5 \mathrm{~s}$ and $5 \mathrm{p}$ sub-shells and the energy levels of the $4 \mathrm{f}$-electrons are weakly influenced by the $\mathrm{RE}^{3+}$ ion vicinity. These transitions are forbidden by Laporte parity rule that is why the f-f transition intensities are weak. However, quite the opposite, the charge-transfer (CT) transition is allowed and strongly affected by electron-lattice coupling. Moreover, its energy level is depended on an ion local symmetry [36-38]. The CT maximum is located at $253 \mathrm{~nm}\left(39,526 \mathrm{~cm}^{-1}\right)$. 


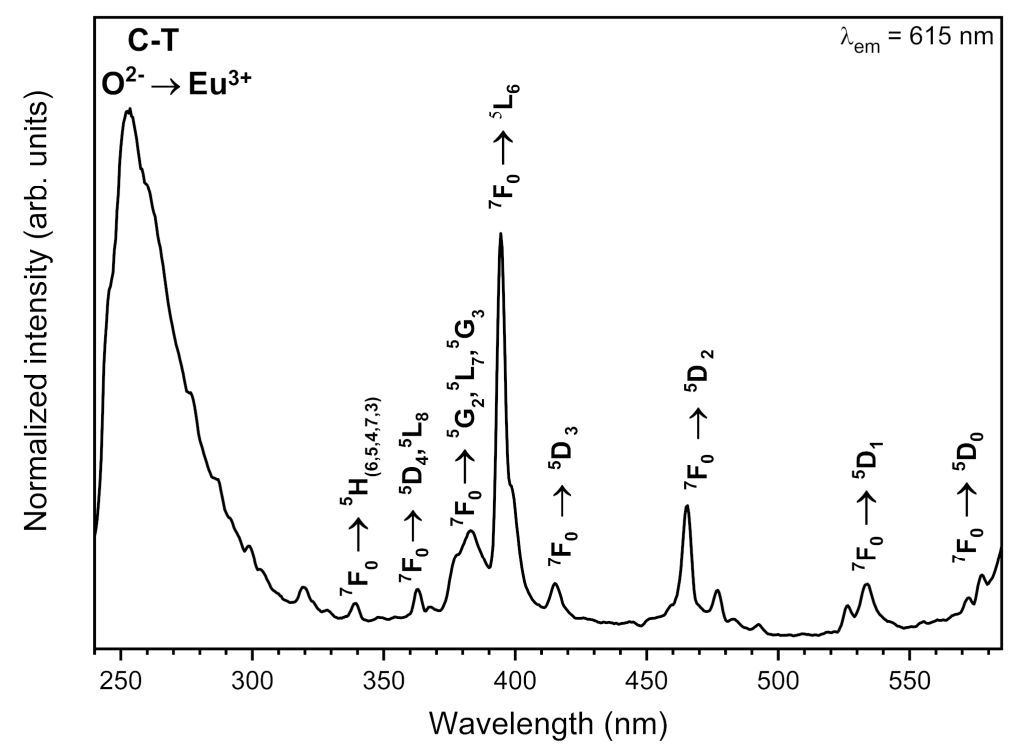

Figure 6. Representative excitation-emission spectra of the $\mathrm{Sr}_{10}\left(\mathrm{PO}_{4}\right)_{6}(\mathrm{OH})_{2}-\mathrm{Sr}_{3}\left(\mathrm{PO}_{4}\right)_{2}$ composite doped with $1 \mathrm{~mol} \% \mathrm{Eu}^{3+}$ ions annealed at $750{ }^{\circ} \mathrm{C}$.

The emission spectra of $x \mathrm{Eu}^{3+}: \mathrm{Sr}_{10}\left(\mathrm{PO}_{4}\right)_{6}(\mathrm{OH})_{2}-\mathrm{Sr}_{3}\left(\mathrm{PO}_{4}\right)_{2}$ (where $\mathrm{x}-0.5-5 \mathrm{~mol} \%$ ) materials annealed at the temperature 750, 850 and $950{ }^{\circ} \mathrm{C}$ were recorded upon pulsed $266 \mathrm{~nm}$ and $395 \mathrm{~nm}$ excitation at $300 \mathrm{~K}$ as well as at $80 \mathrm{~K}$ (Figure 7) and as a function of $\mathrm{Eu}^{3+}$ ions concentration excited by $266 \mathrm{~nm}$ at $300 \mathrm{~K}$ and $80 \mathrm{~K}$ (Figure 8). The spectra excited by $395 \mathrm{~nm}$ line were normalized to the ${ }^{5} \mathrm{D}_{0} \rightarrow{ }^{7} \mathrm{~F}_{1}$ transition, which can be treated as an internal reference. In the emission spectra measured upon excitation by $266 \mathrm{~nm}$, a broad peak at about $421 \mathrm{~nm}$ was observed, which corresponds to the $4 \mathrm{f}^{6} 5 \mathrm{~d}^{1} \rightarrow 4 \mathrm{f}^{7}\left({ }^{8} \mathrm{~S}_{7 / 2}\right)$ emission of $\mathrm{Eu}^{2+}$ ions as well as narrow $4 \mathrm{f}-4 \mathrm{f}$ transitions were present, which are typical for $\mathrm{Eu}^{3+}$ ions. As can be seen, an increase of the annealing temperature results in an increase of the $\mathrm{Eu}^{2+}$ ions emission intensity and a decrease of $\mathrm{Eu}^{3+}$ emission intensity (see Figure 7 upside). The $\mathrm{Eu}^{2+}$ emission measured at $80 \mathrm{~K}$ is less intense compared to the $\mathrm{Eu}^{2+}$ emission measured at $300 \mathrm{~K}$. A change in the annealing temperature and measurement temperature results in changes of the $\mathrm{Eu}^{2+}$ to $\mathrm{Eu}^{3+}$ relative intensity ratio. Moreover, the intensity of the $\mathrm{Eu}^{2+}$ ions emission depends on the measurement temperature and it is more intense in higher temperatures (see Figure 7). This was caused by an increase of $\mathrm{Eu}^{2+}$ fraction in the composite. The detailed description of reduction mechanism is provided in Sections 3.3 and 3.4.

The $\mathrm{Eu}^{3+}$ emission spectra consist of characteristic electron transitions occurring in the $4 \mathrm{f}$ shells appearing in the red region of the electromagnetic radiation. The ${ }^{5} \mathrm{D}_{0} \rightarrow{ }^{7} \mathrm{~F}_{0}$ transition is located at $576.9 \mathrm{~nm}\left(17,334 \mathrm{~cm}^{-1}\right)$, the ${ }^{5} \mathrm{D}_{0} \rightarrow{ }^{7} \mathrm{~F}_{1}$ transition at $585.9 \mathrm{~nm}\left(17,068 \mathrm{~cm}^{-1}\right)$, the ${ }^{5} \mathrm{D}_{0} \rightarrow{ }^{7} \mathrm{~F}_{2}$ transition at $616.5 \mathrm{~nm}\left(16,221 \mathrm{~cm}^{-1}\right)$, the ${ }^{5} \mathrm{D}_{0} \rightarrow{ }^{7} \mathrm{~F}_{3}$ transition at $655.2 \mathrm{~nm}\left(15,262 \mathrm{~cm}^{-1}\right)$, the ${ }^{5} \mathrm{D}_{0} \rightarrow{ }^{7} \mathrm{~F}_{4}$ transition at $700.5 \mathrm{~nm}\left(14,275 \mathrm{~cm}^{-1}\right)$, the ${ }^{5} \mathrm{D}_{0} \rightarrow{ }^{7} \mathrm{~F}_{5}$ transition at $742.7 \mathrm{~nm}\left(13,464 \mathrm{~cm}^{-1}\right)$ and the ${ }^{5} \mathrm{D}_{0} \rightarrow{ }^{7} \mathrm{~F}_{6}$ transition at $805.3 \mathrm{~nm}\left(12,418 \mathrm{~cm}^{-1}\right)$. The ${ }^{5} \mathrm{D}_{0} \rightarrow{ }^{7} \mathrm{~F}_{0}$ transition is split into three components located at $571.6 \mathrm{~nm}$ $\left(17,495 \mathrm{~cm}^{-1}\right), 576.9 \mathrm{~nm}\left(17,334 \mathrm{~cm}^{-1}\right)$ and $579.9 \mathrm{~nm}\left(17,244 \mathrm{~cm}^{-1}\right)$, indicating that $\mathrm{Eu}^{3+}$ ions are located at least into three different crystallographic sites in this composite [39-42]. A difference between the intensity ratio of components is visible. 

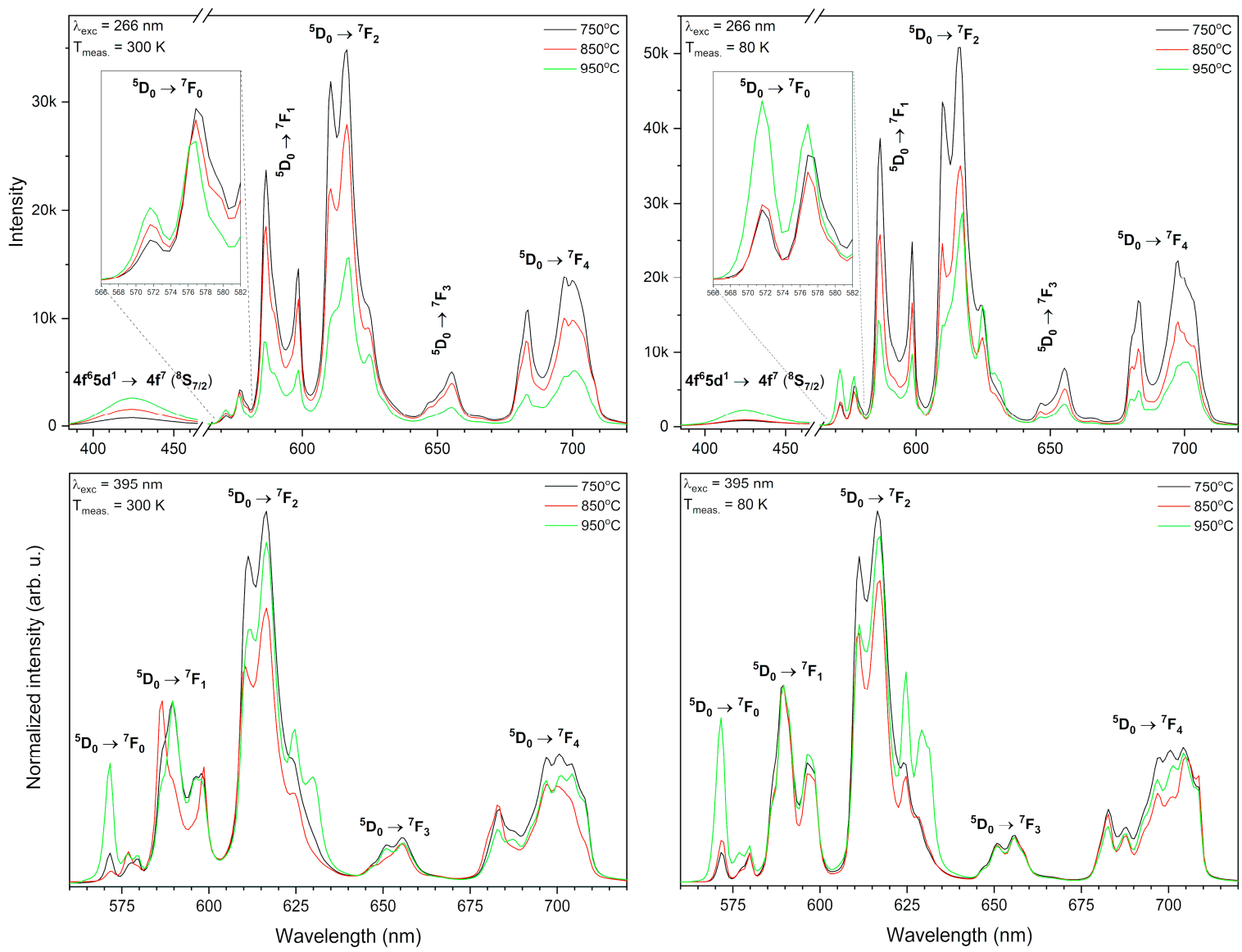

Figure 7. Emission spectra of the $\mathrm{Sr}_{10}\left(\mathrm{PO}_{4}\right)_{6}(\mathrm{OH})_{2}-\mathrm{Sr}_{3}\left(\mathrm{PO}_{4}\right)_{2}$ composite doped with $3 \mathrm{~mol} \%$ Eu ${ }^{3+}$ ions as a function of post-heat treatment temperature excited by $266 \mathrm{~nm}$ (above) and by $395 \mathrm{~nm}$ line (below) measured at $300 \mathrm{~K}$ (left) and $80 \mathrm{~K}$ (right).
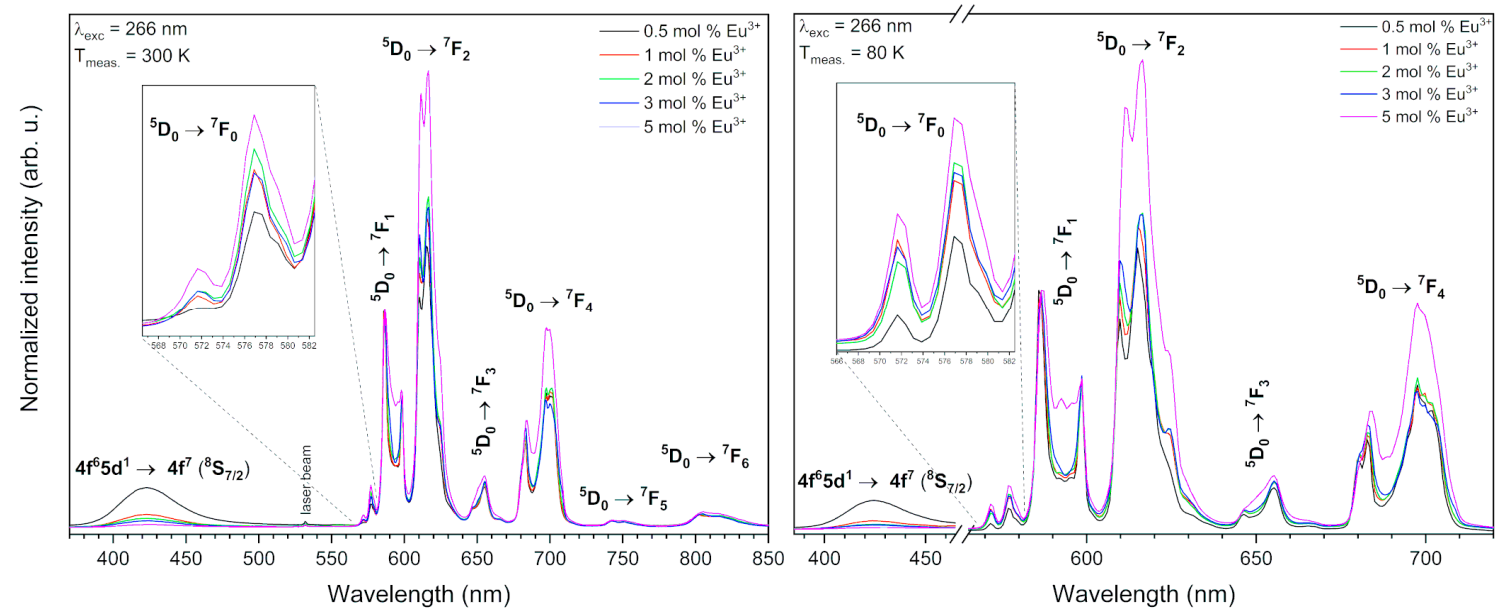

Figure 8. Emission spectra of the $\mathrm{Sr}_{10}\left(\mathrm{PO}_{4}\right)_{6}(\mathrm{OH})_{2}-\mathrm{Sr}_{3}\left(\mathrm{PO}_{4}\right)_{2}$ composite doped with Eu ${ }^{3+}$ ions as a function of the $\mathrm{Eu}^{3+}$ ions concentration annealed at $750{ }^{\circ} \mathrm{C}$, excited by $266 \mathrm{~nm}$ line, measured at $300 \mathrm{~K}$ (left) and $80 \mathrm{~K}$ (right).

The hypersensitive ${ }^{5} \mathrm{D}_{0} \rightarrow{ }^{7} \mathrm{~F}_{2}$ emission transition is the most intense in all cases. The intensity of this transition is very sensitive to variations in the local environment of $\mathrm{Eu}^{3+}$ ions in the host. On the other hand, the intensity of the ${ }^{5} \mathrm{D}_{0} \rightarrow{ }^{7} \mathrm{~F}_{1}$ magnetic dipole transition remains almost independent on the crystal field. When $\mathrm{Eu}^{3+}$ ions occupy a centrosymmetric site, the only permissive 
transition is magnetic one. In the opposite, the electric dipole transition is cardinal. The asymmetry ratio of the relevant emission intensities $(\mathrm{R})$ is defined followingly [43]:

$$
\mathrm{R}=\frac{\int{ }^{5} \mathrm{D}_{0} \rightarrow{ }^{7} \mathrm{~F}_{2}}{\int{ }^{5} \mathrm{D}_{0} \rightarrow{ }^{7} \mathrm{~F}_{1}}
$$

The integrated intensities ratio of these transitions is used to evaluate the asymmetry of the $\mathrm{Eu}^{3+}$ ions coordination polyhedron. The higher the relationship between these transitions is the less centrosymmetric the local environment of $\mathrm{Eu}^{3+}$ ions becomes. The annealing temperatures and $\mathrm{Eu}^{3+}$ ions concentration impacts on the $\mathrm{R}$ value is gathered in Table 2 . Any relationship between an increase of annealing temperature and dopant concentration is not observed. The crystallography sites in phosphate lattice are randomly occupied by $\mathrm{Eu}^{3+}$ ions what is related to the $\mathrm{Eu}^{3+}$ ion concentration and annealing temperature. Moreover, the observed emission is related to different crystallographic sites. That is why the $\mathrm{R}$ value behaves incalculably in such cases.

Table 2. Decay rates of radiative $\left(A_{\text {rad }}\right)$, nonradiative $\left(A_{\text {nrad }}\right)$ and total $\left(A_{\text {tot }}\right)$ processes of the ${ }^{5} D_{0} \rightarrow{ }^{7} F_{J}$ transitions, luminescence lifetimes $(\mathrm{T})$, intensity parameters $\left(\Omega_{2}, \Omega_{4}\right)$, quantum efficiency $(\eta)$ and asymmetry ratio $(\mathrm{R})$ of the $\mathrm{Sr}_{10}\left(\mathrm{PO}_{4}\right)_{6}(\mathrm{OH})_{2}-\mathrm{Sr}_{3}\left(\mathrm{PO}_{4}\right)_{2}$ composites.

\begin{tabular}{|c|c|c|c|c|c|c|c|c|}
\hline \multicolumn{9}{|c|}{$3 \mathrm{~mol} \% \mathrm{Eu}^{3+}: \mathrm{Sr}_{10}\left(\mathrm{PO}_{4}\right)_{6}(\mathrm{OH})_{2}-\mathrm{Sr}_{3}\left(\mathrm{PO}_{4}\right)_{2}$} \\
\hline Sample & $\begin{array}{l}A_{\text {rad }} \\
\left(s^{-1}\right)\end{array}$ & $\begin{array}{c}A_{\text {nrad }} \\
\left(s^{-1}\right)\end{array}$ & $\begin{array}{l}A_{\text {tot }} \\
\left(s^{-1}\right)\end{array}$ & $\mathrm{T}(\mathrm{ms})$ & $\begin{array}{c}\Omega_{2} \\
\left(10^{20} \mathrm{~cm}^{2}\right)\end{array}$ & $\begin{array}{c}\Omega_{4} \\
\left(10^{20} \mathrm{~cm}^{2}\right)\end{array}$ & $\eta(\%)$ & $\mathbf{R}$ \\
\hline $750^{\circ} \mathrm{C}$ & 167.56 & 86.11 & 253.67 & 3.94 & 3.2704 & 3.2757 & 66.05 & 2.321 \\
\hline $850^{\circ} \mathrm{C}$ & 154.13 & 73.81 & 227.94 & 4.39 & 2.9401 & 2.9301 & 67.62 & 2.087 \\
\hline $950^{\circ} \mathrm{C}$ & 164.66 & 150.97 & 315.63 & 3.17 & 3.3232 & 2.9414 & 52.17 & 2.359 \\
\hline \multicolumn{9}{|c|}{$x \mathrm{~mol} \% \mathrm{Eu}^{3+}: \mathrm{Sr}_{10}\left(\mathrm{PO}_{4}\right)_{6}(\mathrm{OH})_{2}-\mathrm{Sr}_{3}\left(\mathrm{PO}_{4}\right)_{2} 750{ }^{\circ} \mathrm{C}$} \\
\hline $0.5 \mathrm{~mol} \% \mathrm{Eu}^{3+}$ & 182.37 & 259.13 & 441.50 & 2.27 & 3.4835 & 3.9733 & 41.31 & 2.473 \\
\hline $1 \mathrm{~mol} \% \mathrm{Eu}^{3+}$ & 199.03 & 190.38 & 389.41 & 2.57 & 4.0504 & 4.0731 & 51.11 & 2.875 \\
\hline $2 \mathrm{~mol} \% \mathrm{Eu}^{3+}$ & 187.74 & 218.58 & 406.32 & 2.46 & 3.7431 & 3.8447 & 46.21 & 2.657 \\
\hline $3 \mathrm{~mol} \% \mathrm{Eu}^{3}$ & 167.56 & 86.11 & 253.67 & 3.94 & 3.2704 & 3.2757 & 66.05 & 2.321 \\
\hline $5 \mathrm{~mol} \% \mathrm{Eu}^{3+}$ & 185.04 & 130.41 & 315.45 & 3.17 & 3.7257 & 3.6728 & 58.66 & 2.645 \\
\hline
\end{tabular}

The Stark's components are better visible in the case of emission spectra measured at $80 \mathrm{~K}$ (see Figure 7). The emission spectra upon excitation by $395 \mathrm{~nm}$ line were also measured to be compared. As can be seen, some differences between these two-excitation lines are well visible as different shapes, ratios, and intensity of transitions. The $3 \mathrm{~mol} \% \mathrm{Eu}^{3+}: \mathrm{Sr}_{10}\left(\mathrm{PO}_{4}\right)_{6}(\mathrm{OH})_{2}-\mathrm{Sr}_{3}\left(\mathrm{PO}_{4}\right)_{2}$ material stands out by the abnormal high intensity of the ${ }^{5} \mathrm{D}_{0} \rightarrow{ }^{7} \mathrm{~F}_{0}$ transition upon excitation by the $395 \mathrm{~nm}$ line.

The emission spectra of the Eu ${ }^{3+}$-doped $\mathrm{Sr}_{10}\left(\mathrm{PO}_{4}\right)_{6}(\mathrm{OH})_{2}-\mathrm{Sr}_{3}\left(\mathrm{PO}_{4}\right)_{2}$ composite depend on the $\mathrm{Eu}^{3+}$ ions concentration measured upon $266 \mathrm{~nm}$ excitation at 300 and $80 \mathrm{~K}$ is presented in the Figure 8 As can be observed, an increase of the europium ions concentration in material led in a decrease of the photoluminescence (PL) intensity of $\mathrm{Eu}^{2+}$ ions. This insight can be caused by the $\mathrm{Eu}^{2+} \rightarrow \mathrm{Eu}^{3+}$ energy transfer, which prompts in the quenching of the $\mathrm{Eu}^{2+}$ emission. In materials doped with low $\mathrm{Eu}^{3+}$ ions concentration, the $\mathrm{Eu}^{2+}$ ions are weakly quenched due to the statistically enormous distance between these two ions. An increase of dopant concentration caused an increase of the $\mathrm{Eu}^{2+} \rightarrow \mathrm{Eu}^{3+}$ energy transfer efficiency as a result of a bigger concentration of ions in the host $[7,44]$. This could also be caused by the different emission intensity in two compounds due to the change of $\operatorname{Sr}_{10}\left(\mathrm{PO}_{4}\right)_{6}(\mathrm{OH})_{2}$ to $\mathrm{Sr}_{3}\left(\mathrm{PO}_{4}\right)_{2}$ proportion with an increase of Eu ions doping.

On the other hand, the decrease of $\mathrm{Eu}^{2+} \mathrm{PL}$ intensity may be clarified by the fact that the amount of $\mathrm{V}^{\prime \prime} \mathrm{Sr}$ vacancies also increase with an increase of the $\mathrm{Eu}^{3+}$ concentration and an excess of the $\mathrm{Eu}^{3+}$ ions would occupy the $\mathrm{V}^{\prime \prime}$ sr position. Consequently, the double negative vacancy $\left(\mathrm{V}^{\prime \prime}\right.$ sr $)$ would be 
converted into a positive charge hereupon, it cannot move negative charge to $\mathrm{Eu}^{3+}$ and the reduction was inhibited. To have electroneutrality, the composite may absorb oxygen from air.

The $\Omega_{2}$ and $\Omega_{4}$ intensity parameters was calculated based on the Judd-Ofelt theory and the results are listed in Table 2 . The $\Omega_{2}$ parameter value changes lightly with an increase of $\mathrm{Eu}^{3+}$ ion concentration and with an increase of annealing temperature, but without any well visible tendency. It indicates the changes in the europium coordination polyhedra and could be related to changes of the $\mathrm{Eu}^{3+}-\mathrm{O}^{2-}$ bond covalency. The $\Omega_{4}$ value brings information about the electron density variations around $\mathrm{Eu}^{3+}$ cations. However, the $\mathrm{Eu}^{3+}$ ions symmetry changes cannot be directly interpreted by the $\Omega_{4}$ value but can add some information about the electron density deviations in the $\mathrm{O}^{2-}$ anions surrounding, what influences on the CT band position.

\subsection{Abnormal Reduction Mechanism of $\mathrm{Eu}^{3+} \rightarrow E u^{2+}$}

The abnormal reduction of the $\mathrm{Eu}^{3+}$ to the $\mathrm{Eu}^{2+}$ ion is known in the literature for solid-state materials made at elevated temperature in air [45-47]. Su et al. introduced four demands for these abnormal reductions of the $\mathrm{Eu}^{3+}$ ions to the $\mathrm{Eu}^{2+}$ ions in a solid-state host:

(1) no oxidizing ions are present in compounds,

(2) the $\mathrm{Eu}^{3+}$ ions substitute the cations with lower valences in compounds,

(3) similar radii of the substituted cation and $\mathrm{Eu}^{2+}$ ion, and

(4) the tetrahedral anion groups $\left(\mathrm{BO}_{4}, \mathrm{PO}_{4}, \mathrm{AlO}_{4}, \mathrm{SiO}_{4}\right)$ are present in compound [47].

In the $\mathrm{Sr}_{10}\left(\mathrm{PO}_{4}\right)_{6}(\mathrm{OH})_{2}-\mathrm{Sr}_{3}\left(\mathrm{PO}_{4}\right)_{2}$ composite, the $\mathrm{Sr}^{2+}$ and $\mathrm{P}^{5+}$ are not oxidizing ions, which satisfied condition (1). The $\mathrm{Eu}^{3+}$ ions substituted $\mathrm{Sr}^{2+}$ sites in this composite, which means that $\mathrm{Eu}^{3+}$ ions substituted cations with lower valences. Moreover, the $\mathrm{Sr}^{2+}$ ion has similar radii to $\mathrm{Eu}^{2+}$ (in hydroxyapatite: $\mathrm{Sr}^{2+}(\mathrm{CN} 9)-1.31 \AA, \mathrm{Eu}^{2+}(\mathrm{CN} 9)-1.30 \AA$ and $\mathrm{Sr}^{2+}(\mathrm{CN} 7)-1.21 \AA, \mathrm{Eu}^{2+}$ (CN7)-1.20 ̊), in tristrontium diphosphate: $\mathrm{Sr}^{2+}(\mathrm{CN} 6)-1.18 \AA, \mathrm{Eu}^{2+}(\mathrm{CN} 6)-1.17 \AA$ and $\mathrm{Sr}^{2+}$ (CN10)-1.36 $\AA, \mathrm{Eu}^{3+}$ (CN9)-1.35 $\AA$ [29]) and meet conditions (2) and (3). Furthermore, the condition (4) is also achieved, because this composite is built by $\mathrm{PO}_{4}{ }^{3-}$ anions groups. Based on this conditions and emission spectra, it is expected that the $\mathrm{Eu}^{3+}$ to $\mathrm{Eu}^{2+}$ reduction occur in these composites. The $\mathrm{Eu}^{3+}$ ions were partially reduced to the $\mathrm{Eu}^{2+}$ and this reduction in composites obtained in air atmosphere at elevated temperature can be clarified by the charge compensation mechanism based on the Kröger-Vink-notation ( ${ }^{*}$ sign means charge neutrality, ${ }^{\bullet}$ means positive charge and ' negative charge in particular crystallographic site. The vacancy is marked by $\mathrm{V}$ and interstitial atom by ${ }_{\mathrm{i}}$ ). When the trivalent $\mathrm{Eu}^{3+}$ ions substituted the $\mathrm{Sr}^{2+}$ ions, two $\mathrm{Eu}^{3+}$ ions would substitute for three $\mathrm{Sr}^{2+}$ ions to preserve charge electroneutrality and a double negative vacancy in the Sr crystallographic site $\left(\mathrm{V}^{\prime \prime} \mathrm{Sr}\right)$ is created. Consequently, two $\mathrm{Eu}^{\bullet}$ Sr positive defects and one $\mathrm{V}^{\prime \prime} \mathrm{Sr}$ negative vacancy would be designed by each substitution for every two $\mathrm{Eu}^{3+}$ ions:

$$
\mathrm{Eu}_{2} \mathrm{O}_{3}+3 \mathrm{Sr}^{*} \mathrm{Sr} \rightarrow 2\left(\mathrm{Eu}^{3+}\right)^{\bullet} \mathrm{Sr}+\mathrm{V}^{\prime \prime} \mathrm{Sr}+3 \mathrm{CaO}
$$

Two relative negative charges are composed on the hydroxyl sides:

$$
\mathrm{Eu}_{2} \mathrm{O}_{3}+2 \mathrm{Ca}^{*} \mathrm{Ca}+2 \mathrm{OH}^{*} \mathrm{OH} \rightarrow 2\left(\mathrm{Eu}^{3+}\right)^{\bullet} \mathrm{Ca}+2 \mathrm{O}_{\mathrm{OH}}^{\prime}+2 \mathrm{CaO}+\mathrm{H}_{2} \mathrm{O}
$$

In addition, charge balance can also be reached by the creation of interstitial oxygen $\mathrm{O}^{\prime \prime}{ }_{i}$ with double relative negative charge:

$$
\mathrm{Eu}_{2} \mathrm{O}_{3}+2 \mathrm{Ca}^{*} \mathrm{Ca} \rightarrow 2\left(\mathrm{Eu}^{3+}\right)^{\bullet} \mathrm{Ca}+\mathrm{O}^{\prime \prime}{ }_{i}+2 \mathrm{CaO}
$$


The vacancy $\mathrm{V}^{\prime \prime}$ Sr could behave as a donor of electrons pending the two $\mathrm{Eu}^{\bullet} \mathrm{Sr}$ defects turn into acceptors of electrons. Via thermal stimulation, the negative charges of the $\mathrm{V}^{\prime \prime}$ Sr vacancy defects would be thereafter moved to the $\mathrm{Eu}^{3+}$ positions and reduce them to their $\mathrm{Eu}^{2+}$ form followingly:

$$
2\left(\mathrm{Eu}^{3+}\right)_{\mathrm{Sr}}^{\bullet}+\mathrm{V}_{\mathrm{Sr}}^{\prime \prime} \rightarrow 2\left(\mathrm{Eu}^{2+}\right)_{\mathrm{Sr}}^{*}+\mathrm{V}_{\mathrm{Sr}}^{*}
$$

The higher annealing temperature, the mechanism of the $\mathrm{Eu}^{3+}$ to $\mathrm{Eu}^{2+}$ reduction is more probable, which is well visible on the emission spectra.

\subsection{Thermal Stability}

The luminescence intensity of the $1 \mathrm{~mol} \% \mathrm{Eu}^{3+}: \mathrm{Sr}_{10}\left(\mathrm{PO}_{4}\right)_{6}(\mathrm{OH})_{2}-\mathrm{Sr}_{3}\left(\mathrm{PO}_{4}\right)_{2}$ was measured depending on the measurement temperature in the range of 80-550 K (see Figure 9). It was observed that the PL intensity of $\mathrm{Eu}^{3+}$ ion decreases with an increase of the measurement temperature but on the other hand the PL intensity of $\mathrm{Eu}^{2+}$ ion increases. Mechanism of this behavior has been described as abnormal intense $\mathrm{Eu}^{2+}$ emission in high temperature [16,48]. It could be related to the presence of two possible defect traps of $\left[2\left(\mathrm{Eu}^{3+}\right)^{\bullet} \mathrm{Sr}-\mathrm{O}_{\mathrm{i}}{ }^{\prime \prime}\right]$ or $\left[2\left(\mathrm{Eu}^{3+}\right)_{\mathrm{Sr}}{ }^{\bullet}-\mathrm{V}_{\mathrm{Sr}^{\prime \prime}}\right]$ in this material. The $\mathrm{Eu}^{3+}$ ions could recombined with the electrons released from defects $\mathrm{O}_{\mathrm{i}}{ }^{\prime \prime}$ or $\mathrm{V}_{\mathrm{Sr}}$ "; nevertheless, the electrons do not get into the $\mathrm{Eu}^{2+}$ ion but loosely couple with $\mathrm{Eu}^{3+}$ in the near environment $\left(\mathrm{Eu}^{3+}+\mathrm{e}^{-}\right)$manifesting emission of $\mathrm{Eu}^{2+}$. All the defects can be inert at low temperature what yield low luminescence of $\mathrm{Eu}^{2+}$ ion when the temperature decrease. The CIE 1931 chromaticity diagram is presented in the Figure 10 determined from emission spectra measured in 80,300 and $550 \mathrm{~K}$ of temperature.

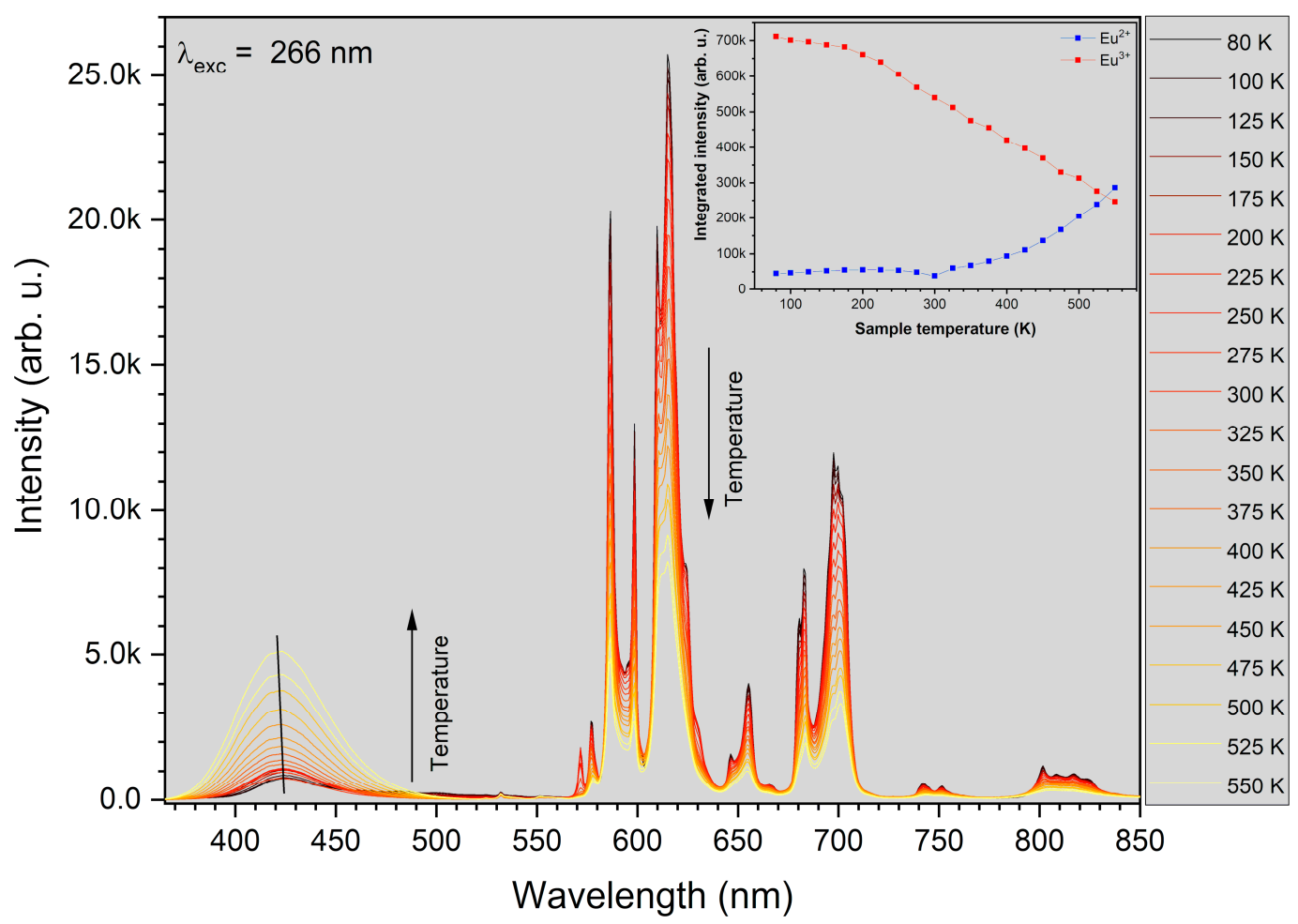

Figure 9. The luminescence intensity dependence on the measurement temperature of $1 \mathrm{~mol} \% \mathrm{Eu}^{3+}$ : $\mathrm{Sr}_{10}\left(\mathrm{PO}_{4}\right)_{6}(\mathrm{OH})_{2}-\mathrm{Sr}_{3}\left(\mathrm{PO}_{4}\right)_{2}$ in the temperature range of 80-550 K. Inset: dependence of integrated intensity of the $\mathrm{Eu}^{2+}$ and $\mathrm{Eu}^{3+}$ emission on the measurement temperature. 


\section{CIE 1931}

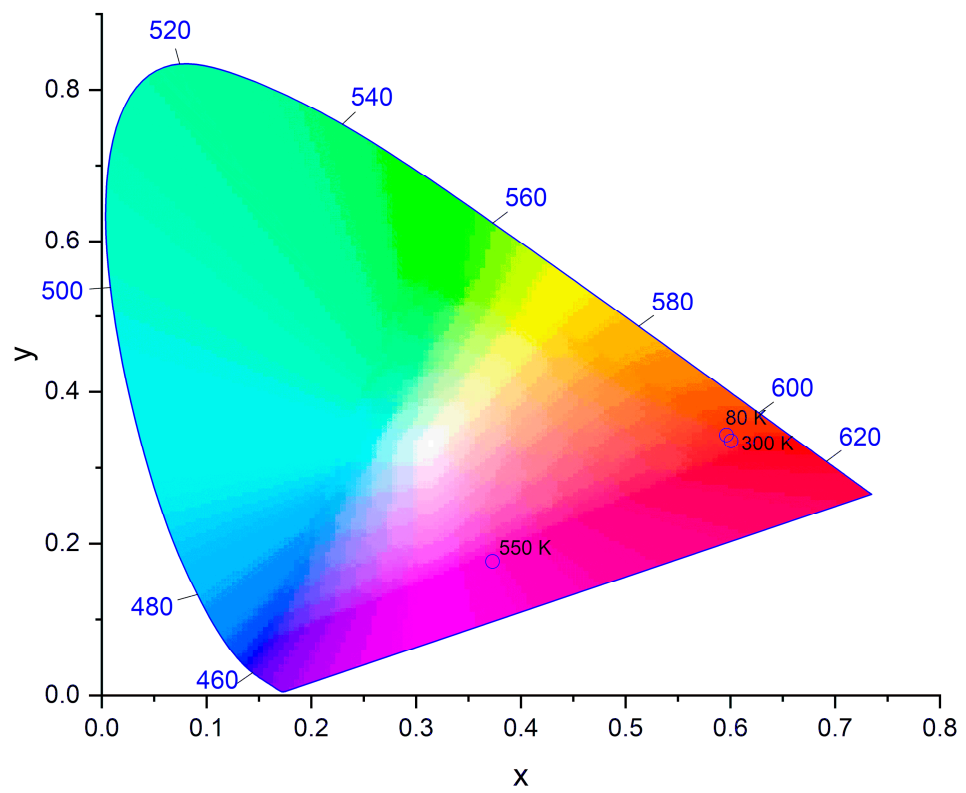

Figure 10. CIE chromaticity coordinates values of the $1 \mathrm{~mol} \% \mathrm{Eu}^{3+}: \mathrm{Sr}_{10}\left(\mathrm{PO}_{4}\right)_{6}(\mathrm{OH})_{2}-\mathrm{Sr}_{3}\left(\mathrm{PO}_{4}\right)_{2}$ excited by $266 \mathrm{~nm}$ and measured in 80,300 and $550 \mathrm{~K}$ of temperature.

\subsection{Fluorescence Dynamics}

The luminescence kinetics were analyzed for all synthesized materials to determine the comprehensive characteristics of the luminescence properties. The decay times at room temperature (RT) corresponding to the ${ }^{5} \mathrm{D}_{0} \rightarrow{ }^{7} \mathrm{~F}_{2}$ transition were excited by pulse radiation of $395 \mathrm{~nm}$ and monitored at $615 \mathrm{~nm}$ (Figure 11). The decay curves are not single-exponential, what is compatible with the presence of nonequivalent crystallographic sites of $\mathrm{Eu}^{3+}$ ions accordingly, the lifetimes values were calculated as the effective emission decay time by using Equation (1). The decay profiles and the lifetime values are alike to each other and only minor differences were observed. The decay times of $\mathrm{Eu}^{3+}$ ions in $\mathrm{Sr}_{10}\left(\mathrm{PO}_{4}\right)_{6}(\mathrm{OH})_{2}-\mathrm{Sr}_{3}\left(\mathrm{PO}_{4}\right)_{2}$ are typical for this kind of ion and are longer than for strontium apatite $[7,8]$, which is caused by the presence of $\mathrm{Sr}_{3}\left(\mathrm{PO}_{4}\right)_{2}$ phase.
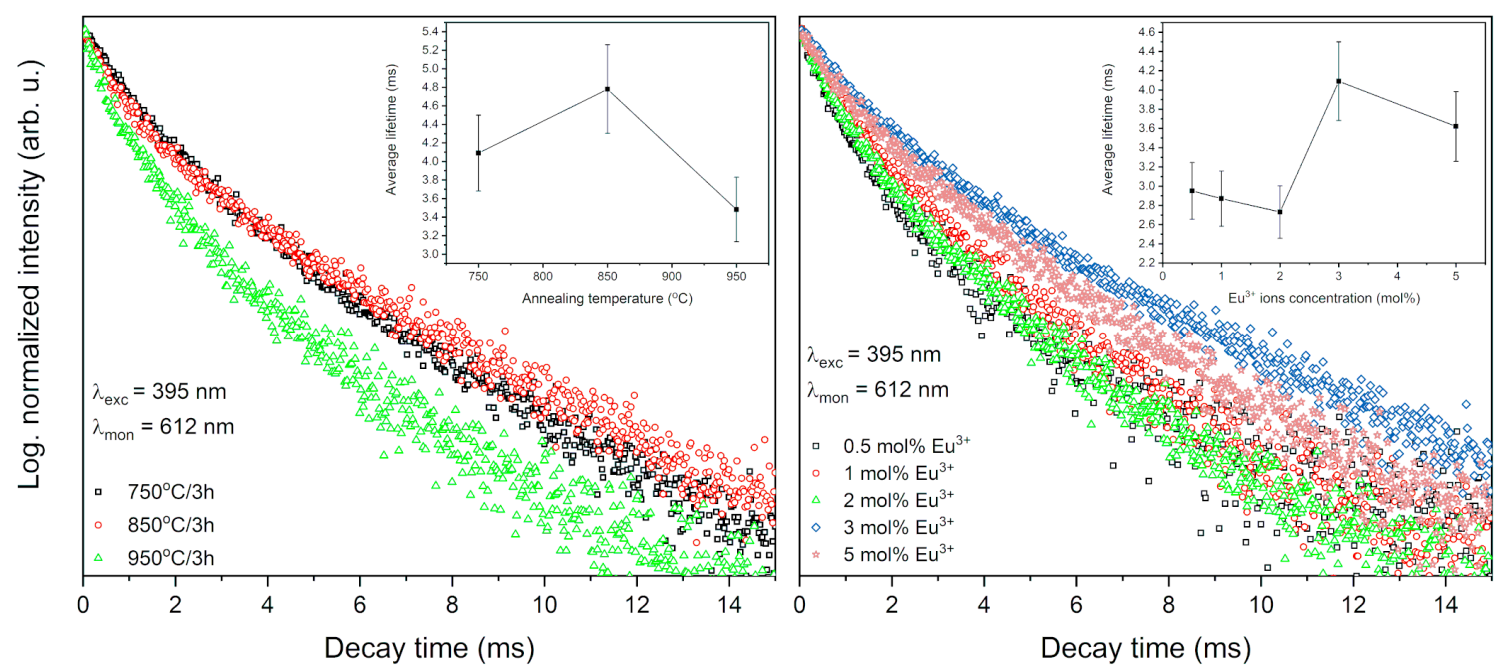

Figure 11. Luminescence kinetics of the $\mathrm{Sr}_{10}\left(\mathrm{PO}_{4}\right)_{6}(\mathrm{OH})_{2}-\mathrm{Sr}_{3}\left(\mathrm{PO}_{4}\right)_{2}$ composite doped with 3 mol\% $\mathrm{Eu}^{3+}$ ions as a function of heat-treatment temperature (left) and annealed composite at $750{ }^{\circ} \mathrm{C}$ as a function of europium ions concentration (right). 
The decay curve (blue component) of the $1 \mathrm{~mol} \% \mathrm{Eu}^{3+}: \mathrm{Sr}_{10}\left(\mathrm{PO}_{4}\right)_{6}(\mathrm{OH})_{2}-\mathrm{Sr}_{3}\left(\mathrm{PO}_{4}\right)_{2}$ composite annealed at $750{ }^{\circ} \mathrm{C}$ was measured under excitation at $266 \mathrm{~nm}$ and monitored at $430 \mathrm{~nm}$ (Figure 12). The single exponential shape of the decay curve indicates to the $\mathrm{Eu}^{2+}$ ion emission from one crystallographic site. The lifetime value was calculated based on Equation (2) and was determined to be $0.674 \mu \mathrm{s}$. The emission spectra of blue emission from the streak camera is presented in Figure 13.

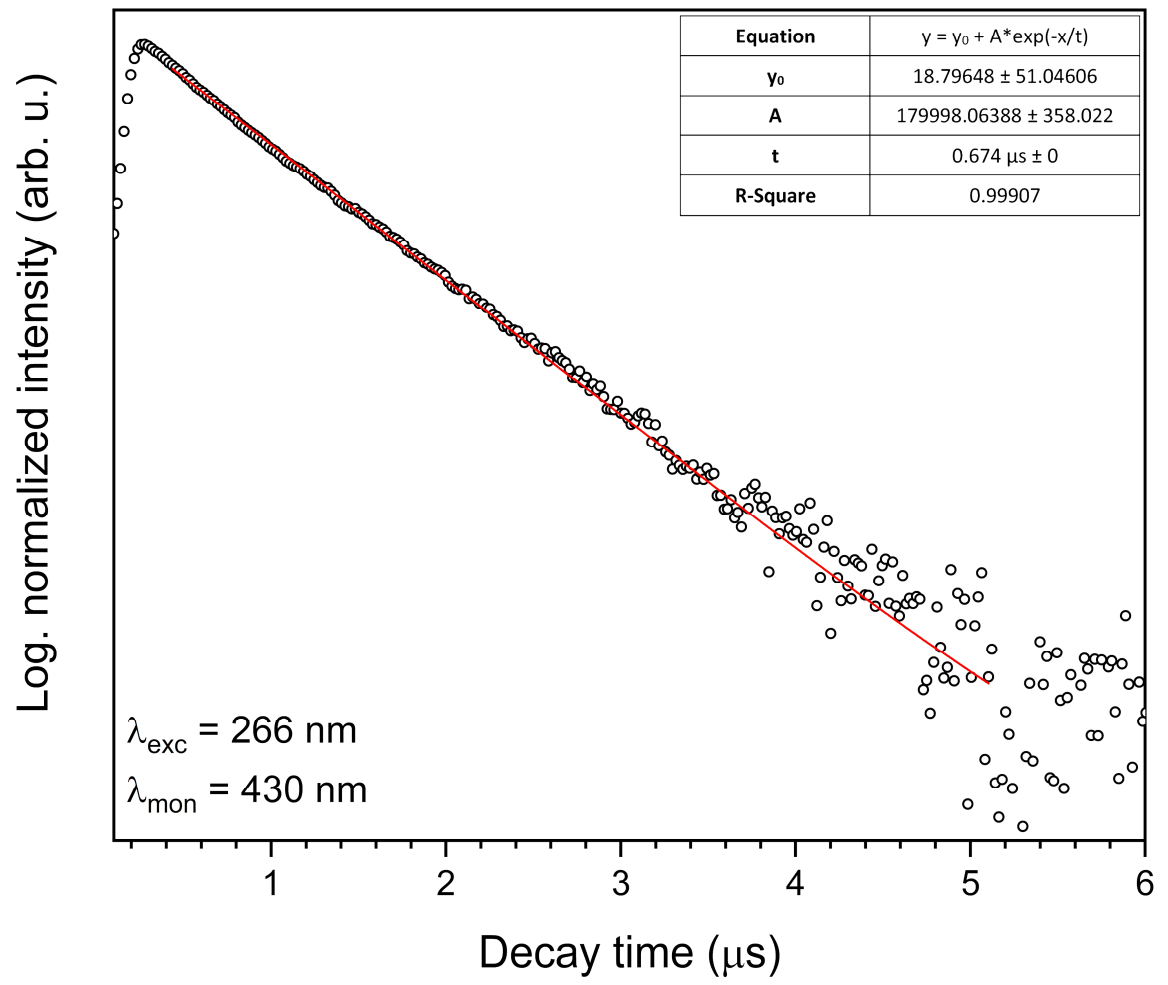

Figure 12. Luminescence kinetics of the blue component of the $1 \mathrm{~mol} \% \mathrm{Eu}^{3+}$ : $\mathrm{Sr}_{10}\left(\mathrm{PO}_{4}\right)_{6}(\mathrm{OH})_{2}-\mathrm{Sr}_{3}\left(\mathrm{PO}_{4}\right)_{2}$ composite annealed at $750{ }^{\circ} \mathrm{C}$. Excited by $266 \mathrm{~nm}$ and observed at $430 \mathrm{~nm}$.

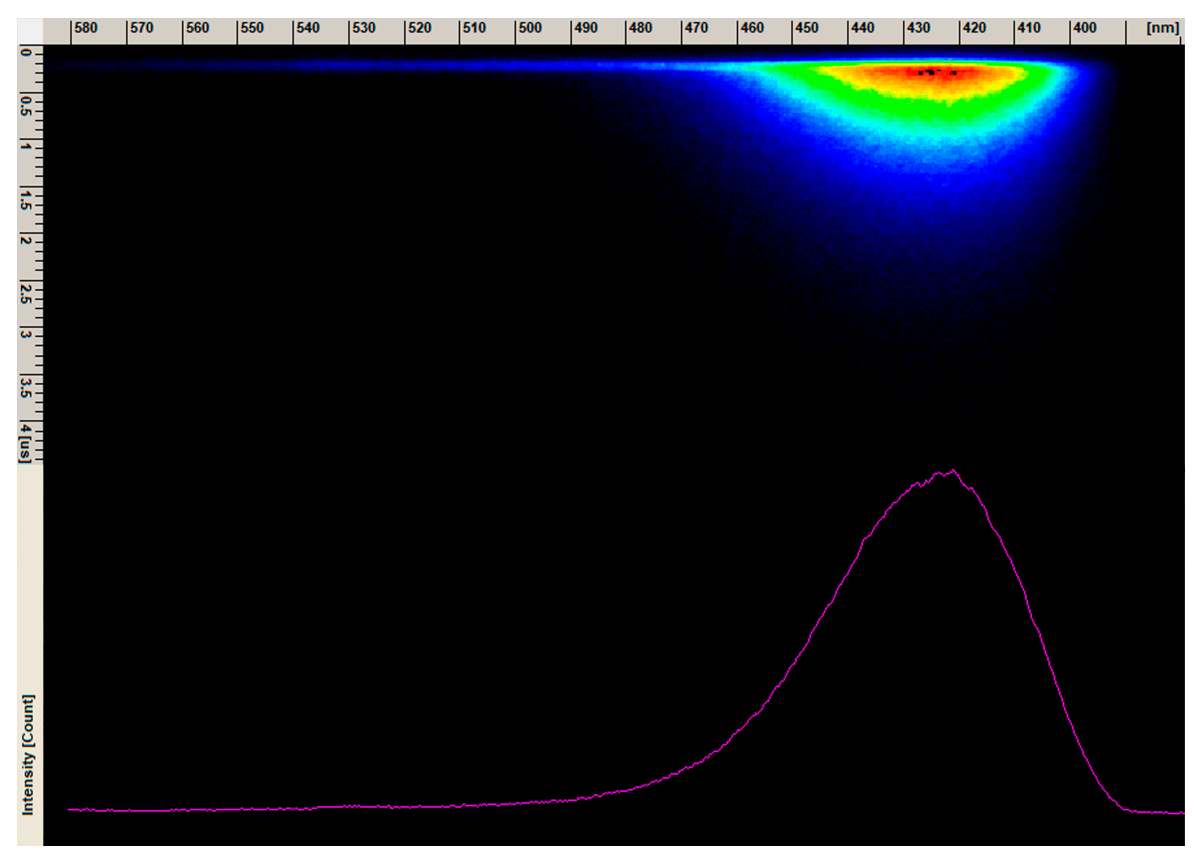

Figure 13. The emission spectrum image form streak camera of the $1 \mathrm{~mol} \% \mathrm{Eu}^{3+}$ : $\mathrm{Sr}_{10}\left(\mathrm{PO}_{4}\right)_{6}(\mathrm{OH})_{2}-\mathrm{Sr}_{3}\left(\mathrm{PO}_{4}\right)_{2}$ composite annealed at $750{ }^{\circ} \mathrm{C}$. 


\section{Conclusions}

A microwave-assisted hydrothermal method was used with success to produce $\mathrm{Eu}^{3+}$-doped $\mathrm{Sr}_{10}\left(\mathrm{PO}_{4}\right)_{6}(\mathrm{OH})_{2}-\mathrm{Sr}_{3}\left(\mathrm{PO}_{4}\right)_{2}$ composites. The structural and luminescence properties were investigated in a function of dopant ions concentration and annealing temperature. The formation of the strontium phosphate composite was confirmed by the XRPD analysis. The unit cell parameters as well as the percentage content of crystal phases, were calculated by Rietveld refinement method. The obtained materials have had a tendency to agglomerate to minimize their excess surface energy and their shapes were irregular and elongated. There were no observed changes in morphology with an increase of the annealing temperature. There were observed the narrow $4 \mathrm{f}-4 \mathrm{f}$ transitions typical for $\mathrm{Eu}^{3+}$ ions and a broadband at $421 \mathrm{~nm}$ related to the $4 \mathrm{f}^{6} 5 \mathrm{~d}^{1} \rightarrow 4 \mathrm{f}^{7}\left({ }^{8} \mathrm{~S}_{7 / 2}\right)$ transition from $\mathrm{Eu}^{2+}$ ions. Moreover, it has been described as an abnormal intense emission of $\mathrm{Eu}^{2+}$ ion due to recombination of the excited state of $\mathrm{Eu}^{3+}$ ion with the electrons released from defects $\left(\mathrm{O}_{\mathrm{i}}{ }^{\prime \prime}\right.$ or $\left.\mathrm{V}_{\mathrm{Sr}^{\prime \prime}}\right)$.

The decay curves of $\mathrm{Eu}^{3+}$ ions are not single-exponential as a result of the nonequivalent crystallographic sites of $\mathrm{Eu}^{3+}$ ions in the matrix. However, the lifetime value of $\mathrm{Eu}^{2+}$ ions is single-exponential and was determined to be $0.674 \mu \mathrm{s}$.

Author Contributions: Conceptualization, K.S. and R.J.W.; methodology, K.S. and A.W.; investigation, K.S. and A.W.; writing—original draft preparation, K.S.; writing—review and editing, K.S., A.W. and R.J.W.; supervision, R.J.W. All authors have read and agreed to the published version of the manuscript.

Funding: This research received no external funding.

Acknowledgments: The authors would like to thank E. Bukowska for performing XRD measurements, D. Szymanski for SEM measurements and R.M. Kowalski for femtosecond laser measurements.

Conflicts of Interest: The authors declare no conflict of interest.

\section{References}

1. Zhang, X.; Xing, Q.; Liao, L.; Han, Y. Effect of the Fluorine Substitution for-OH Group on the Luminescence Property of $\mathrm{Eu}^{3+}$ Doped Hydroxyapatite. Crystals 2020, 10, 191. [CrossRef]

2. Hidouri, M.; Dorozhkin, S.V. Structure and thermal stability of sodium and carbonate-co-substituted strontium hydroxyfluorapatites. New J. Chem. 2018, 42, 8469-8477. [CrossRef]

3. Roh, H.S.; Lee, S.; Caliskan, S.; Yoon, C.; Lee, J.K. Luminescence and electric dipole in $\mathrm{Eu}^{3+}$ doped strontium phosphate: Effect of $\mathrm{SiO}_{4}$. J. Alloys Compd. 2019, 772, 573-578. [CrossRef]

4. Pogosova, M.A.; González, L.V. Influence of anion substitution on the crystal structure and color properties of copper-doped strontium hydroxyapatite. Ceram. Int. 2018, 44, 20140-20147. [CrossRef]

5. Yilmaz, B.; Alshemary, A.Z.; Evis, Z. Co-doped hydroxyapatites as potential materials for biomedical applications. Microchem. J. 2019, 144, 443-453. [CrossRef]

6. Priyadarshini, B.; Vijayalakshmi, U. Development of cerium and silicon co-doped hydroxyapatite nanopowder and its in vitro biological studies for bone regeneration applications. Adv. Powder Technol. 2018, 29, 2792-2803. [CrossRef]

7. Zawisza, K.; Wiglusz, R.J. Preferential site occupancy of $\mathrm{Eu}^{3+}$ ions in strontium hydroxyapatite nanocrystalline $-\mathrm{Sr}_{10}\left(\mathrm{PO}_{4}\right)_{6}(\mathrm{OH})_{2}$-structural and spectroscopic characterisation. Dalt. Trans. 2017, 46, 3265-3275. [CrossRef]

8. Zawisza, K.; Strzep, A.; Wiglusz, R.J. Influence of annealing temperature on the spectroscopic properties of hydroxyapatite analogues doped with $\mathrm{Eu}^{3+}$. New J. Chem. 2017, 41, 9990-9999. [CrossRef]

9. Gómez-Morales, J.; Verdugo-Escamilla, C.; Fernández-Penas, R.; Parra-Milla, C.M.; Drouet, C.; Maube-Bosc, F.; Oltolina, F.; Prat, M.; Fernández-Sánchez, J.F. Luminescent biomimetic citrate-coated europium-doped carbonated apatite nanoparticles for use in bioimaging: Physico-chemistry and cytocompatibility. RSC Adv. 2018, 8, 2385-2397. [CrossRef]

10. He, W.; Xie, Y.; Xing, Q.; Ni, P.; Han, Y.; Dai, H. Sol-gel synthesis of biocompatible Eu $\mathrm{Eu}^{3+} / \mathrm{Gd}^{3+}$ co-doped calcium phosphate nanocrystals for cell bioimaging. J. Lumin. 2017, 192, 902-909. [CrossRef] 
11. Szyszka, K.; Rewak-Soroczynska, J.; Dorotkiewicz-Jach, A.; Ledwa, K.A.; Piecuch, A.; Giersig, M.; Drulis-Kawa, Z.; Wiglusz, R.J. Structural modification of nanohydroxyapatite Ca10(PO4)6(OH)2 related to $\mathrm{Eu}^{3+}$ and $\mathrm{Sr}^{2+}$ ions doping and its spectroscopic and antimicrobial properties. J. Inorg. Biochem. 2020, 203, 110884. [CrossRef] [PubMed]

12. Zou, H.; Yan, M.; Wang, G.; Yuan, B.; Huang, J.; Gao, F.; Sheng, Y.; Zheng, K.; Song, Y. $\mathrm{Sr}_{5}\left(\mathrm{PO}_{4}\right)_{3} \mathrm{Cl}_{\text {: }} \mathrm{Eu}^{2+}$ with multiform morphologies and sizes: Hydrothermal synthesis and luminescent properties. Powder Technol. 2014, 254, 579-582. [CrossRef]

13. Li, G.; Zhao, Y.; Wei, Y.; Tian, Y.; Quan, Z.; Lin, J. Novel yellowish-green light-emitting $\mathrm{Ca}_{10}\left(\mathrm{PO}_{4}\right)_{6} \mathrm{O}: \mathrm{Ce}^{3+}$ phosphor: Structural refinement, preferential site occupancy and color tuning. Chem. Commun. 2016, 52, 3376-3379. [CrossRef]

14. Xie, Z.; Zhao, W.; Zhou, W.W.; Yang, F.G. Synthesis and luminescence properties of new red phosphor YBiW2O9:Eu ${ }^{3+}$. Funct. Mater. Lett. 2017, 10, 1750066. [CrossRef]

15. Zhang, N.; Guo, C.; Zheng, J.; Su, X.; Zhao, J. Synthesis, electronic structures and luminescent properties of $\mathrm{Eu}^{3+}$ doped KGdTiO4. J. Mater. Chem. C 2014, 2, 3988-3994. [CrossRef]

16. Pan, Y.; Wang, W.; Zhu, Y.; Xu, H.; Noh, H.M.; Jeong, J.H.; Liu, X.; Li, L. Eu ${ }^{3+} \rightarrow \mathrm{Eu}^{2+}$ unusual reduction and bond energy in MAlSi2O6:Eu (M = Li, Na, K, Rb, Cs). Ceram. Int. 2018, 44, 8484-8491. [CrossRef]

17. Heyward, C.C.; Kimani, M.M.; Moore, C.A.; McMillen, C.D.; Kolis, J.W. Europium valence control in the hydrothermal synthesis of apatites and borosilicates. J. Alloys Compd. 2016, 656, 206-212. [CrossRef]

18. Baran, A.; Mahlik, S.; Grinberg, M.; Cai, P.; Kim, S.I.; Seo, H.J. Luminescence properties of different Eu sites in LiMgPO4:Eu ${ }^{2+}, \mathrm{Eu}^{3+}$. J. Phys. Condens. Matter 2014, 26, 385401. [CrossRef]

19. Grandhe, B.K.; Bandi, V.R.; Jang, K.; Kim, S.S.; Shin, D.S.; Lee, Y.I.; Lim, J.M.; Song, T. Reduction of Eu ${ }^{3+}$ to $\mathrm{Eu}^{2+}$ in NaCaPO4:Eu phosphors prepared in a non-reducing atmosphere. J. Alloys Compd. 2011, 509, 7937-7942. [CrossRef]

20. Pei, Z.; Zeng, Q.; Su, Q. A Study on the Mechanism of the Abnormal Reduction of $\mathrm{Eu}^{3+} \rightarrow \mathrm{Eu}^{2+}$ in $\mathrm{Sr} 2 \mathrm{~B} 5 \mathrm{O} 9 \mathrm{Cl}$ Prepared in Air at High Temperature. J. Solid State Chem. 1999, 145, 212-215. [CrossRef]

21. Cheng, L.; Zhang, W.; Li, Y.; Dai, S.; Chen, X.; Qiu, K. Synthesis and photoluminescence properties of $\mathrm{Sr}_{3}\left(\mathrm{PO}_{4}\right)_{2}: \mathrm{Re}^{3+}, \mathrm{Li}^{+}(\mathrm{Re}=\mathrm{Eu}, \mathrm{Sm})$ red phosphors for white light-emitting diodes. Ceram. Int. 2017, 43, 11244-11249. [CrossRef]

22. Ha, L.T.; Tu, N.; Quang, N.V.; Thang, C.X.; Vuong, P.H.; Viet, D.X.; Hung, N.D.; Kien, N.D.T.; Duong, T.-T.; Lien, N.T.K.; et al. Effect of doping concentration and sintering temperature on structure and photoluminescence properties of blue/red emitting bi-phase $\mathrm{Eu}^{3+} / \mathrm{Eu}^{2+}$-doped $\mathrm{Sr}_{5}\left(\mathrm{PO}_{4}\right)_{3} \mathrm{Cl} / \mathrm{Sr}_{3}\left(\mathrm{PO}_{4}\right)_{2}$ phosphors. Mater. Res. Express 2018, 5, 076516. [CrossRef]

23. Huang, Y.; Gan, J.; Seo, H.J. Luminescence Investigation of Eu-Activated $\mathrm{Sr}_{5}\left(\mathrm{PO}_{4}\right)_{2} \mathrm{SiO}_{4}$ Phosphor by Combustion Synthesis. J. Am. Ceram. Soc. 2011, 94, 1143-1148. [CrossRef]

24. El Ouenzerfi, R.; Kbir-Ariguib, N.; Trabelsi-Ayedi, M.; Piriou, B. Spectroscopic study of Eu ${ }^{3+}$ in strontium hydroxyapatite $\mathrm{Sr}_{10}\left(\mathrm{PO}_{4}\right)_{6}(\mathrm{OH})_{2}$. J. Lumin. 1999, 85, 71-77. [CrossRef]

25. Rietveld, H.M.; Nederland, R.C. A profile refinement method for nuclear and magnetic structures. J. Appl. Crystallogr. 1969, 2, 65-71. [CrossRef]

26. Lutterotti, L.; Matthies, S.; Wenk, H.R. MAUD: A friendly Java program for Material Analysis Using Diffraction. IUCr Newsl. CPD 1999, 21, 14-15. [CrossRef]

27. Sudarsanan, K.; Young, R.A. Structure of strontium hydroxide phosphate, $\mathrm{Sr}_{5}\left(\mathrm{PO}_{4}\right)_{3} \mathrm{OH}$. Acta Crystallogr. Sect. B 1972, 28, 3668-3670. [CrossRef]

28. Manoun, B.; Popović, L.; De Waal, D.; Verryn, S.M.C. Rietveld refinements of a new solid solution $\mathrm{Ba}(3-\mathrm{x})$ Srx (PO4) 2 (0 $\leq x \leq 3)$. Powder Diffr. 2003, 18, 122-127. [CrossRef]

29. Shannon, R.D. Revised effective ionic radii and systematic studies of interatomic distances in halides and chalcogenides. Acta Crystallogr. Sect. A 1976, 32, 751-767. [CrossRef]

30. Badraoui, B.; Bigi, A.; Debbabi, M.; Gazzano, M.; Roveri, N.; Thouvenot, R. Physicochemical Properties and Structural Refinement of Strontium-Lead Hydroxyapatites. Eur. J. Inorg. Chem. 2002, 2002, 1864-1870.

31. Han, Y.; Wang, X.; Dai, H.; Li, S. Synthesis and luminescence of $\mathrm{Eu}^{3+}$ doped hydroxyapatite nanocrystallines: Effects of calcinations and $\mathrm{Eu}^{3+}$ content. J. Lumin. 2013, 135, 281-287. [CrossRef]

32. Chen, F.; Yuan, X.; Zhang, F.; Wang, S. Photoluminescence properties of $\mathrm{Sr}_{3}\left(\mathrm{PO}_{4}\right)_{2}$ :Eu ${ }^{2+}, \mathrm{Dy}^{3+}$ double-emitting blue phosphor for white LEDs. Opt. Mater. 2014, 37, 65-69. [CrossRef] 
33. Banerjee, S.S.; Tarafder, S.; Davies, N.M.; Bandyopadhyay, A.; Bose, S. Understanding the influence of MgO and SrO binary doping on the mechanical and biological properties of b-TCP ceramics. Acta Biomater. 2010, 6, 4167-4174. [CrossRef] [PubMed]

34. Li, K.; Shang, M.; Geng, D.; Lian, H.; Zhang, Y.; Fan, J.; Lin, J. Synthesis, Luminescence, and Energy-Transfer Properties of $\beta-\mathrm{Na}_{2} \mathrm{Ca}_{4}\left(\mathrm{PO}_{4}\right)_{2}\left(\mathrm{SiO}_{4}\right): \mathrm{A}\left(\mathrm{A}=\mathrm{Eu}^{2+}, \mathrm{Dy}^{3+}, \mathrm{Ce}^{3+} / \mathrm{Tb}^{3+}\right)$ Phosphors. Inorg. Chem. 2014, 53, 6743-6751. [CrossRef]

35. Gopi, D.; Sathishkumar, S.; Karthika, A.; Kavitha, L. Development of $\mathrm{Ce}^{3+} / \mathrm{Eu}^{3+}$ dual-substituted hydroxyapatite coating on surgical grade stainless steel for improved antimicrobial and bioactive properties. Ind. Eng. Chem. Res. 2014, 53, 20145-20153. [CrossRef]

36. Tanner, P.A. Lanthanide Luminescence in Solids. In Lanthanide Luminescence: Photophysical, Analytical and Biological Aspects; Hanninen, P., Harma, H., Eds.; Springer-Verlag: Berlin/Heidelberg, Germany, 2010; pp. 183-233.

37. Blasse, G. On the $\mathrm{Eu}^{3+}$ Fluorescence of Mixed Metal Oxides. IV. The Photoluminescent Efficiency of $\mathrm{Eu}^{3+}$-Activated Oxides. J. Chem. Phys. 1966, 45, 2356-2360. [CrossRef]

38. Dorenbos, $\mathrm{P}$. The $\mathrm{Eu}^{3+}$ charge transfer energy and the relation with the band gap of compounds. J. Lumin. 2005, 111, 89-104. [CrossRef]

39. Ternane, R.; Ferid, M.; Panczer, G.; Trabelsi-Ayadi, M.; Boulon, G. Site-selective spectroscopy of Eu ${ }^{3+}$-doped orthorhombic lanthanum and monoclinic yttrium polyphosphates. Opt. Mater. 2005, 27, 1832-1838. [CrossRef]

40. Silva, D.; Abreu, A.; Davolos, M.R.R.; Rosaly, M. Determination of the local site occupancy of Eu3+ ions in ZnAl2O4 nanocrystalline powders. Opt. Mater. 2011, 33, 1226-1233. [CrossRef]

41. Seo, H.J.; Du, F.; Nakai, Y.; Tsuboi, T.; Huang, Y.; Seo, H.J.; Du, F.; Nakai, Y.; Tsuboi, T.; Huang, Y.; et al. Luminescence properties and site occupations of $\mathrm{Eu}^{3+}$ ions doped in double phosphates $\mathrm{Ca}_{9} \mathrm{R}\left(\mathrm{PO}_{4}\right)_{7}(\mathrm{R}=\mathrm{Al}$, Lu). J. Mater. Chem. 2011, 21, 4669. [CrossRef]

42. Watras, A.; Boutinaud, P.; Pazik, R.; Dereń, P.J.J.; Pazik, R.; Dereń, P.J.J. Luminescence-Structure relationships in MYP2O7:Eu ${ }^{3+}(\mathrm{M}=\mathrm{K}, \mathrm{Rb}, \mathrm{Cs})$. J. Lumin. 2016, 175, 249-254. [CrossRef]

43. Kolesnikov, I.E.; Povolotskiy, A.V.; Mamonova, D.V.; Kolesnikov, E.Y.; Kurochkin, A.V.; Lähderanta, E.; Mikhailov, M.D. Asymmetry ratio as a parameter of Eu3+ local environment in phosphors. J. Rare Earths 2018, 36, 474-481. [CrossRef]

44. Targonska, S.; Szyszka, K.; Rewak-Soroczynska, J.; Wiglusz, R.J. A new approach to spectroscopic and structural studies of the nano-sized silicate-substituted hydroxyapatite doped with Eu3+ ions. Dalt. Trans. 2019, 48, 8303-8316. [CrossRef] [PubMed]

45. Liu, J.; Liang, K.; Wu, Z.C.; Mei, Y.M.; Kuang, S.P.; Li, D.X. The reduction of $\mathrm{Eu}^{3+}$ to $\mathrm{Eu}^{2+}$ in a new orange-red emission $\mathrm{Sr}_{3} \mathrm{P}_{4} \mathrm{O}_{13}$ : Eu phosphor prepared in air and its photoluminescence properties. Ceram. Int. 2014, 40, 8827-8831. [CrossRef]

46. Peng, M.; Pei, Z.; Hong, G.; Su, Q. The reduction of $\mathrm{Eu}^{3+}$ to $\mathrm{Eu}^{2+}$ in $\mathrm{BaMgSiO}_{4}$ : Eu prepared in air and the luminescence of $\mathrm{BaMgSiO}_{4}$ : Eu ${ }^{2+}$ phosphor. J. Mater. Chem. 2003, 13, 1202-1205. [CrossRef]

47. Pei, Z.; Su, Q.; Zhang, J. The valence change from $\mathrm{RE}^{3+}$ to $\mathrm{RE}^{2+}(\mathrm{RE}=\mathrm{Eu}, \mathrm{Sm}, \mathrm{Yb})$ in SrB4O7: RE prepared in air and the spectral properties of $\mathrm{RE}^{2+}$. J. Alloys Compd. 1993, 198, 51-53. [CrossRef]

48. Xie, H.; Lu, J.; Guan, Y.; Huang, Y.; Wei, D.; Seo, H.J. Abnormal Reduction, $\mathrm{Eu}^{3+} \rightarrow \mathrm{Eu}^{2+}$, and Defect Centers in $\mathrm{Eu}^{3+}$-Doped Pollucite, $\mathrm{CsAlSi}_{2} \mathrm{O}_{6}$, Prepared in an Oxidizing Atmosphere. Inorg. Chem. 2014, 53, 827-834. [CrossRef] [PubMed]

(C) 2020 by the authors. Licensee MDPI, Basel, Switzerland. This article is an open access article distributed under the terms and conditions of the Creative Commons Attribution (CC BY) license (http://creativecommons.org/licenses/by/4.0/). 